\title{
Impact of Macroeconomic Policies on Stock Market in Mongolia
}

\author{
Namjil Enkhbaatar \\ Saitama University, Saitama, Japan
}

\begin{abstract}
According to the extensive literature, many factors affect the stock market by either direct way or indirect way. This study aims to investigate the adverse impacts of fiscal policy and monetary policies on stock market in Mongolia by using monthly data over the period January 2003 to December 2017 and applying a vector-autoregressive (VAR) model, with the predictions that fiscal crowding-out effect and too high policy rate would lower the stock price and stocks traded value. The empirical analysis in this study indicates that stock price and stocks traded value respond negatively to the shocks of policy rate and government securities traded value, respectively. In other words, the accumulated government debt and too high policy rate have crowded out the private investments in stock market and lowered the stock price by increasing riskiness of stocks or reducing the firms' net worth, which is consistent with the main predictions of this study. Therefore, to enhance the contribution of stock market for sustainable economic growth, government and authorities need to engage in implementing macro prudent and sound economic policies from the long-term perspective. When government securities are considered as a fiscal policy tool, it is significant for government to reduce the accumulated government debt and obtain the normalization of domestic bond yield through improving tax-based financing rather than government debt financing. Regarding the monetary policy, it is crucial to obtain the benchmark policy rate among Asian economies with addressing significant factors affecting the high policy rate including macroeconomic condition, balance of payment, exchange rate fluctuations, financial intermediation, and deposit holders base.
\end{abstract}

Keywords: stock market, fiscal policy, government securities, crowding-out effect, monetary policy, policy rate, vector autoregressive model

\section{Introduction}

\section{Capital Market Development in Mongolia}

The main functions of financial system are to allocate capital resources and facilitate financial services such as saving money, borrowing, raising funds, exchanging assets, managing risks for investors and clients through the intermediation provided by financial institutions. In particular, the primary role of financial institutions and capital market is to allocate capital efficiency, that is, to allocate funds to the investment projects with the highest marginal product of capital (Bekaert \& Harvey, 1997). Furthermore, the mechanism of capital allocation and its flows of funds from lenders to borrowers could be classified as indirect finance and direct finance in terms of maturity of funds, intermediation, capital requirements. Figure 1 illustrates the basic functions of allocation of funds for indirect finance and direct finance. In money market, an indirect finance is

Namjil Enkhbaatar, M.E (Master of Economics), Graduate School of Humanities and Social Sciences, Saitama University, Saitama, Japan

Correspondence concerning this article should be addressed to Namjil Enkhbaatar, Faculty of Economics, Saitama University, 255 Shim o-Okubo, Sakura-ku, Saitama 338-8570, Japan. 
often conducted through financial institutions and borrowers are restricted to use only money market instruments which typically mature in less than one year.

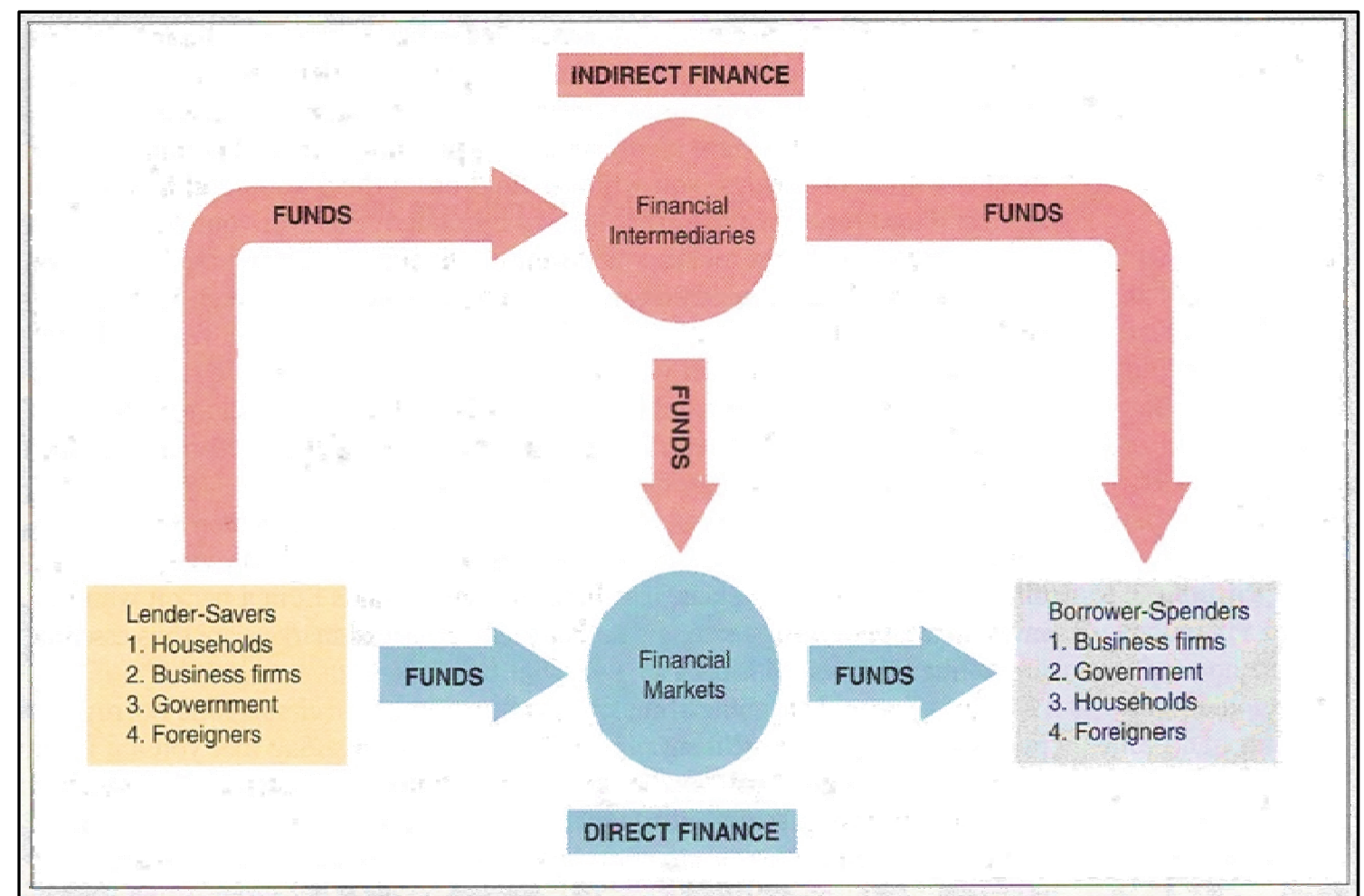

Figure 1. Flows of funds through financial system. Source: Mishkin, F. S. (2016b), An overview of financial system, The Economics of money, banking, and financial markets.

In capital market, the direct finance is considered by investment firms, professionals as a main instrument of raising funds for matured, financially capable private companies which are seeking long-term investments. For example, issuers namely, government, businesses, private firms, institutional investors prefer direct finance rather than indirect finance. To raise additional funds, they offer securities $/ \mathrm{IPO}^{1} /$ to the both foreign and domestic investors without using intermediation provided by financial institutions. However, during the process of offering securities to the public, firms usually contract with investment banks ${ }^{2}$ that provide them investment services and help them sell their new securities in the primary market.

From the perspective of indirect finance and direct finance, it is crucial to analyze the funding structure of financial markets and financial deepening in terms of intermediation of funds. In Mongolia, the financial market is basically dominated by the banking industry. On the other hand, financial system is solely dependent on development of banking industry and efficiency of financial institutions which intermediate indirect finance in financial market. Over the past two decades, the function of financial institutions has been deepened substantially compared to the financial market in Mongolia.

\footnotetext{
${ }^{1}$ Initial Public Offering (IPO) refers to process of offering securities to the public for the first time.

${ }^{2}$ Investment bank or underwriter refers to financial intermediary which provides investment services for issuers and helps them find the enough buyers or subscribers of their securities. See the website (https://www.investopedia.com/terms/i/investment-banki ng.asp).
} 


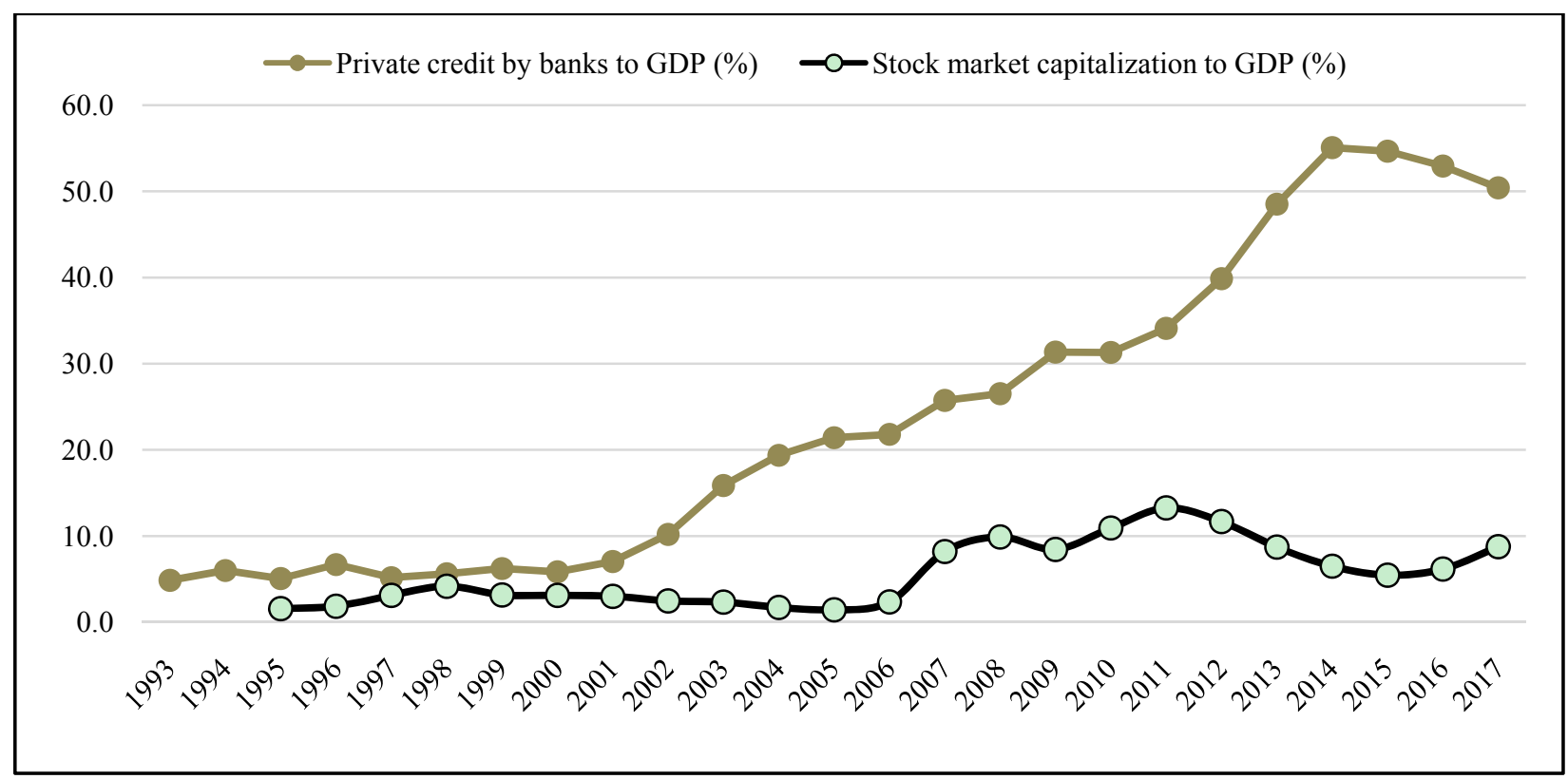

Figure 2. Financial markets and financial institutions' depth in Mongolia. Source: Global Financial Development Database (July 2018 Version) by the World Bank, the stock market capitalization to GDP for 2013-2017 based on the statistical database of the Bank of Mongolia and annual report of Financial Regulatory Commission, private credit by banks to GDP for 2017 is retrieved from data.worldbank.org.

Figure 2 illustrates the trends of depth of financial market and financial institutions in Mongolia from 1993 to 2017. Although some regulatory reforms ${ }^{3}$ have been implemented by government and financial regulators in recent years, the capital market development is still far behind the banking industry in Mongolia in terms of financial deepening, intermediation of funds. Caporale, Howells, and Soliman (2004) implied that if the financial market is only composed of banks, an efficient allocation of capital due to the shortcomings in the financing of debt, in the presence of asymmetric information could not be attained. In 2017, the banking industry consisted of about 95.0 percent of total assets in financial market of Mongolia, and remaining shares or 5.0 percent went to non-bank financial industries including capital market, insurance, microfinance according to the database ${ }^{4}$ of Central bank of Mongolia (Bank of Mongolia) and Financial Regulatory Commission.

In other words, most shares of productive long-term investments have been intermediated by financial institutions instead of being financed by domestic capital market, which simply indicates an inefficient function (allocation of funds) of financial system in Mongolia. The size of the banking industry was being considered by researchers as a proxy measure for financial development over the past decades. Despite the larger size of the banking industry, it is unable to show the quality, efficiency, and stability, since the banking industry is only one component of financial systems (Čihák, Demirgüç-Kunt, Feyen, \& Levine, 2012). Therefore, it is important to measure the financial development in each country through analyzing components of financial system and comparing their proxy indicators. Since the 1970s, most of empirical literatures have approximated the financial development by two measures of financial depth - the ratios of private credit to GDP and stock market capitalization to GDP (Svirydzenka, 2016).

\footnotetext{
${ }^{3}$ Law on the Asset Backed Securities (2011), Revision of Company Law (2011), Revision of Securities market law (2013), Law on Investment Fund were passed by Parliament of Mongolia (2013).

${ }^{4}$ Details on assets of financial institutions have been summarized in Table 1.
} 
Table 1

Structure of Financial Market in Mongolia

\begin{tabular}{lllllll}
\hline & \multicolumn{2}{c}{2015} & \multicolumn{2}{c}{2016} & \multicolumn{2}{c}{2017} \\
\cline { 2 - 7 } & $\begin{array}{l}\text { Financial } \\
\text { institutions }\end{array}$ & $\begin{array}{l}\text { Assets /MNT } \\
\text { billions/ }\end{array}$ & $\begin{array}{l}\text { Financial } \\
\text { institutions }\end{array}$ & $\begin{array}{l}\text { Assets /MNT } \\
\text { billions/ }\end{array}$ & $\begin{array}{l}\text { Financial } \\
\text { institutions }\end{array}$ & $\begin{array}{l}\text { Assets /MNT } \\
\text { billions/ }\end{array}$ \\
\hline Banks & 14 & 21,521 & 14 & 25,338 & 14 & 28,773 \\
Nonbanks & 782 & 962 & 876 & 1199 & 892 & 1459 \\
Capital market* & 62 & 68 & 62 & 91 & 52 & 92 \\
Insurance & 16 & 173 & 16 & 208 & 16 & 245 \\
SCC $^{* *}$ & 253 & 98 & 280 & 113 & 290 & 153 \\
NBFI*** & 450 & 623 & 518 & 787 & 534 & 969 \\
Total & 1577 & 23,445 & 890 & 26,214 & 906 & 30,232 \\
\hline
\end{tabular}

Notes. *Brokers, Dealers, Underwriters, **Savings and Credit Cooperatives, ***Non-bank Financial Institutions. Source: Statistical database of Bank of Mongolia and Quarterly reports of non-bank financial industries prepared by Financial Regulatory Commission.

Regarding the financial depth as mentioned above, Mongolian financial position can be compared with selected Asian economies in Figure 3, which illustrates the scatter charts between financial depth and GDP per capita $^{5}$ in 2016. Asian economies including "East Asia \& Pacific", "Central Asia", and "South Asia" are selected according to the classification (by region) of World Bank. In the first scatter chart, the depth of financial institutions (private credit by banks to GDP, 52.9\%) in Mongolia is around on the average position (68.0\%) among Asian economies. But the depth of financial market (stock market capitalization to GDP, 6.2\%) in Mongolia is far behind the average of Asian economies (67.3\%). Otherwise, comparisons above imply that the large gap between development of banking industry and capital market in Mongolia.

Table 2

New Broad-Based Index of Financial Development (IMF)

\begin{tabular}{|c|c|c|}
\hline \multicolumn{3}{|c|}{ Financial development index } \\
\hline Financi & institutions index & Financial markets index \\
\hline $\begin{array}{l}\text { 華 } \\
\stackrel{0}{0}\end{array}$ & $\begin{array}{l}\text { Private-sector credit (\% of GDP) } \\
\text { Pension fund assets }(\% \text { of GDP) } \\
\text { Mutual fund assets }(\% \text { of GDP) } \\
\text { Insurance premiums, life and non-life } \\
(\% \text { of GDP) }\end{array}$ & $\begin{array}{l}\text { Stock market capitalization to GDP } \\
\text { Stocks traded to GDP } \\
\text { International debt securities government } \\
\text { (\% of GDP) } \\
\text { Total debt securities of nonfinancial corporations (\% of GDP) } \\
\text { Total debt securities of financial corporations } \\
(\% \text { of GDP) }\end{array}$ \\
\hline 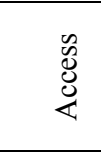 & $\begin{array}{l}\text { Branches (commercial banks) per } 100,000 \text { adults } \\
\text { ATMs per } 100,000 \text { adults }\end{array}$ & $\begin{array}{l}\text { Percent of market capitalization outside of top } 10 \text { largest } \\
\text { companies } \\
\text { Total number of issuers of debt (domestic and external, } \\
\text { nonfinancial corporations, and financial corporations) }\end{array}$ \\
\hline 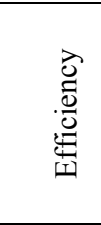 & $\begin{array}{l}\text { Net interest margin } \\
\text { Lending-deposits spread } \\
\text { Non-interest income to total income } \\
\text { Overhead costs to total assets } \\
\text { Return on assets } \\
\text { Return on equity }\end{array}$ & $\begin{array}{l}\text { Stock market turnover ratio } \\
\text { (stocks traded/market capitalization) }\end{array}$ \\
\hline
\end{tabular}

Source: Rethinking Financial Deepening: Stability and Growth in Emerging Markets, IMF staff discussion note (2015).

${ }^{5}$ GDP per capita here regarded as an indicator shows the development stages among Asian economies. 


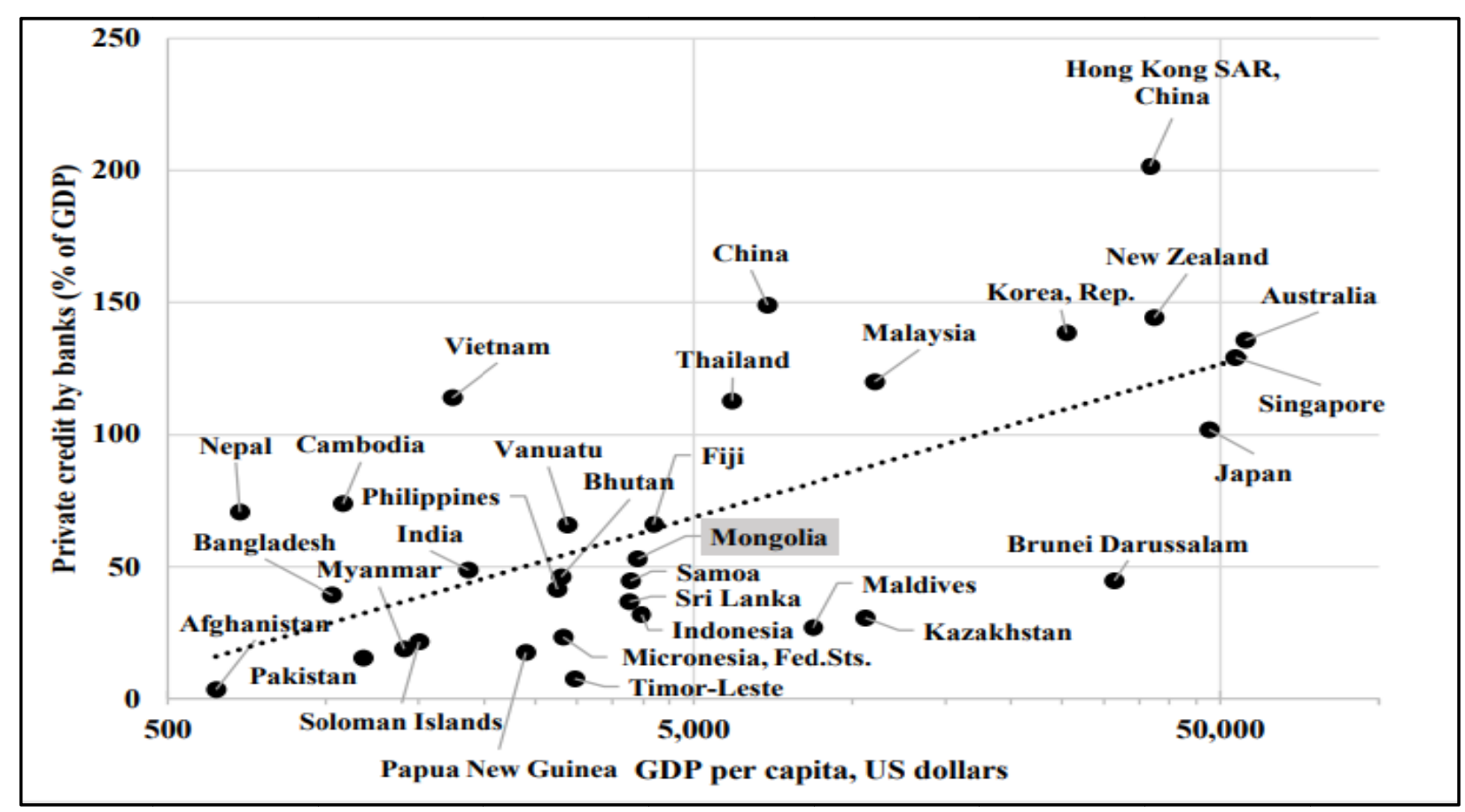

[Private Credit by Banks (Indirect finance)]

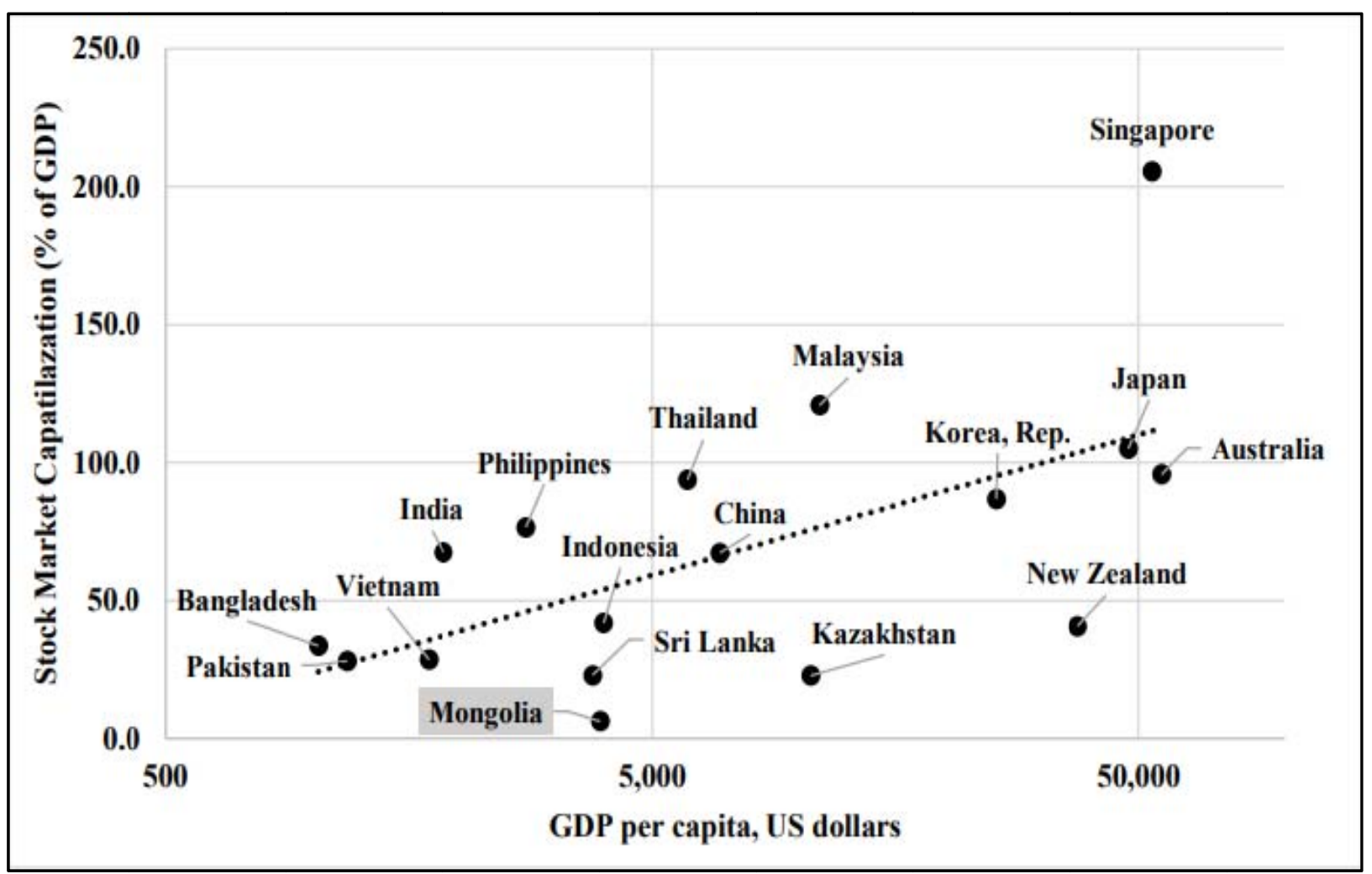

[Stock Market Capitalization (Direct finance)]

Figure 3. Financial depth and GDP per capita in Asian economies (2016). Source: Global Financial Development Database (July 2018 Version) prepared by the World Bank, the annual report (2016) of Financial Regulatory Commission, and statistical database of World Bank (https://www.data.worldbank.org). 
In addition to the assessment of financial development above, Sahay, Čihák, Diaye, Barajas, Ayala, Gao, Kyobe, Nguyen, Saborowski, Svirydzenka, and Yousefi (2015) in the IMF Staff Discussion Note constructed the new broad-based index ${ }^{6}$ of financial development based on the matrix of financial system characteristics developed by Čihák, Demirgüç-Kunt, Feyen, and Levine (2012). The new broad-based index has been introduced in more details by Svirydzenka (2016) in the IMF working paper. According to it, the overall index (financial development) comprises the sub-indices (financial institutions, financial markets), which are based on the combination of depth (size and liquidity of markets), access (ability of individuals to access financial services), and efficiency (ability of institutions to provide financial services at low cost and with sustainable revenues, and the level of activity of capital markets). Figure 4 illustrates the scatter plot between financial institutions index and financial markets index in Asian economies. In 2016, Mongolian financial institutions index (0.6) exceeded the average index ${ }^{7}(0.4)$ of 183 countries and average index (0.5) of selected Asian economies, respectively. Thus, Mongolian banking industry has already reached the higher level of development as mentioned above, which simply indicates the better financial inclusion. The banking industry has been providing financial services at lower transaction cost and facilitating access to financial services more efficiently. On the other hand, financial markets index (0.2) is below the average index (0.4) of Asian economies and almost on the average index (0.2) of 183 countries. As indicated in Figure 3, in Mongolia, the capital market is still underdeveloped compared to the banking industry.

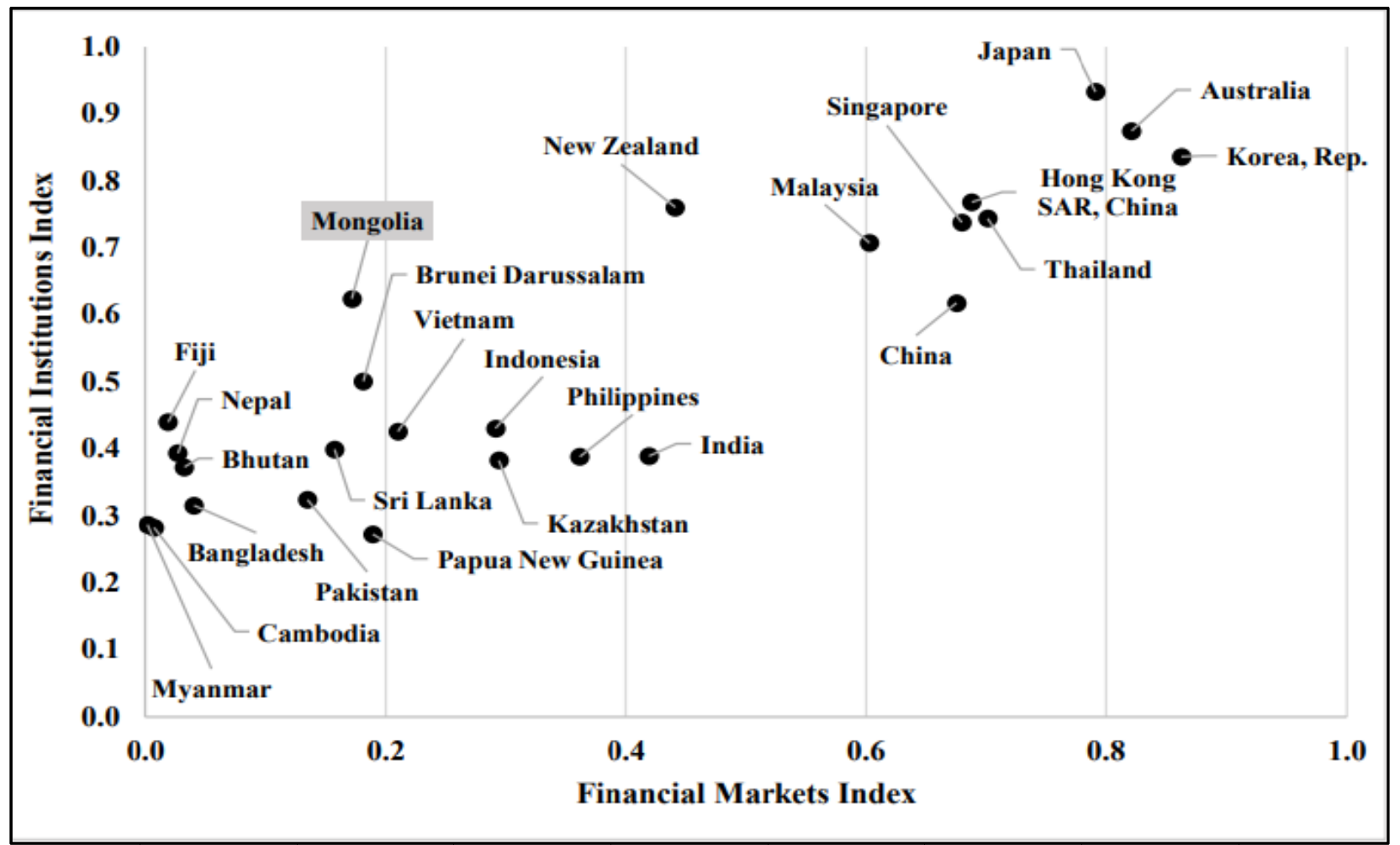

Figure 4. Financial development in Asian economies (2016). Source: IMF Financial Development Index Database (Excel), which is retrieved from statistical database of IMF (https://www.data.imf.org).

6 The IMF financial development index and its sub-indices have been summarized in Table 2.

7 Average index is based on the financial development index database (IMF), see the website (http://data.imf.org/?sk=F8032E80-B36C-43B1-AC26-493C5B1CD33B). 
Table 3

The Structure of Financial Supervision

\begin{tabular}{|c|c|c|}
\hline Regulation & & Country \\
\hline $\begin{array}{l}\text { Institutional } \\
\text { approach }\end{array}$ & $\begin{array}{l}\text { The institutional approach is one in which a firm's legal status (for example, a } \\
\text { bank, broker-dealer, or insurance company) determines which regulator is tasked } \\
\text { with overseeing its activity from both a safety and soundness and a business } \\
\text { conduct perspective. }\end{array}$ & $\begin{array}{l}\text { Hong Kong, China, } \\
\text { Mexico, Mongolia }\end{array}$ \\
\hline $\begin{array}{l}\text { Functional } \\
\text { approach }\end{array}$ & $\begin{array}{l}\text { The functional approach is one in which supervisory oversight is determined by the } \\
\text { business that is being transacted by the entity, without regard to its legal status. } \\
\text { Each type of business may have its own functional regulator. }\end{array}$ & $\begin{array}{l}\text { Brazil, France, } \\
\text { Italy, Spain }\end{array}$ \\
\hline Integrated approach & $\begin{array}{l}\text { The integrated approach is one in which a single universal regulator conducts both } \\
\text { safety and soundness oversight and conduct-of-business regulation for all the } \\
\text { sectors of financial services business. }\end{array}$ & $\begin{array}{l}\text { Canada, Germany, } \\
\text { Japan, Singapore, } \\
\text { Switzerland, United } \\
\text { Kingdom }\end{array}$ \\
\hline $\begin{array}{l}\text { Twin peaks } \\
\text { approach }\end{array}$ & $\begin{array}{l}\text { The twin peaks approach, a form of regulation by objective, is one in which there } \\
\text { is a separation of regulatory functions between two regulators: one that performs } \\
\text { the safety and soundness supervision function and the other that focuses on } \\
\text { conduct-of-business regulation. }\end{array}$ & USA \\
\hline
\end{tabular}

Source: The Structure of Financial Supervision: Approaches and Challenges in a Global Market place prepared by G30 (2008).

The level of capital market development depends on not only one factor but many institutional factorsregulatory and legal framework (supervision, enforcement tools), market infrastructure (trading and settlement systems), corporate governance and transparency of public companies, and other factors (El-Wassal, 2013). According to the annual report (2016) of Financial Regulatory Commission of Mongolia, financial regulator considers the following main factors as problematic issues in capital market development in Mongolia: inefficiency of market infrastructure, lack of regulatory mandate ${ }^{8}$, public financial literacy (institutional factors), inadequate investors base and participation of institutional investors (demand factors), limited number of financial products such as IPOs, corporate bonds, mutual funds, derivates (supply factors), high concentration of listed companies, lower stock market turnover ratio (financial markets efficiency). While the factors above are related directly to the capital market development, El-Wassal (2013) emphasized that so called "supporting block", particularly, macroeconomic policies are crucial for development of stock market and that if the supporting blocks are inadequate, the markets would not function and would not become a developed market (relationship between macroeconomic policies and stock market in Mongolia would be introduced in the following section).

\section{Current Macroeconomic Condition and Stock Market}

Mongolia upgraded its economic status from "low income" to "middle income" in 2007, and is currently considered by World Bank as a lower middle-income economy ${ }^{9}$. Mongolian economic structure is typically based on the mining sector contribution ${ }^{10}$ in terms of real GDP. While Mongolia has large deposits of coal, copper, gold, and other minerals, it in turn makes the economy significantly sensitive to external shocks of global commodity markets. According to the IMF estimations ${ }^{11}$, the real GDP growth in Mongolia averaged 8.6 percent during 2010-2016 as indicated in Figure 5. In particular, the growth rate reached the highest level

\footnotetext{
${ }^{8}$ Regulatory mandate refers to the regulators' legal authority to supervise financial industries and its details of regulatory framework have been summarized in Table 3 .

9 See the website: https://datahelpdesk.worldbank.org/knowledgebase/articles/906519.

${ }_{10}$ Mongolian economic structure by sector classification has been summarized in Table 4.

11 See the website: https://www.imf.org/external/datamapper.
} 
(17.3\%) in history of Mongolian economy in 2011 due to the increase in commodity prices and large amount of inflow FDI in the mining sector.

Table 4

Mongolian Economic Structure (2017)

\begin{tabular}{lll}
\hline Sectors & GDP (MNT billions) & GDP (\%) \\
\hline Agriculture, forestry and fishing & $2,240.49$ & 13 \\
Mining and quarrying & $3,746.37$ & 22 \\
Manufacturing & $1,095.01$ & 6 \\
Construction & 598.68 & 4 \\
Wholesale and retail trade; repair of motor vehicles and motorcycles & $2,101.70$ & 12 \\
Transportation and storage & $1,276.40$ & 8 \\
Financial and insurance activities & $1,128.92$ & 7 \\
Real estate activities & 871.26 & 5 \\
Education services & 415.74 & 2 \\
Others & $3,411.52$ & 20 \\
Total value: (real GDP) & $16,886.10$ & 100 \\
\hline
\end{tabular}

Source: Statistical database of National Statistics Office of Mongolia (http://1212.mn/).

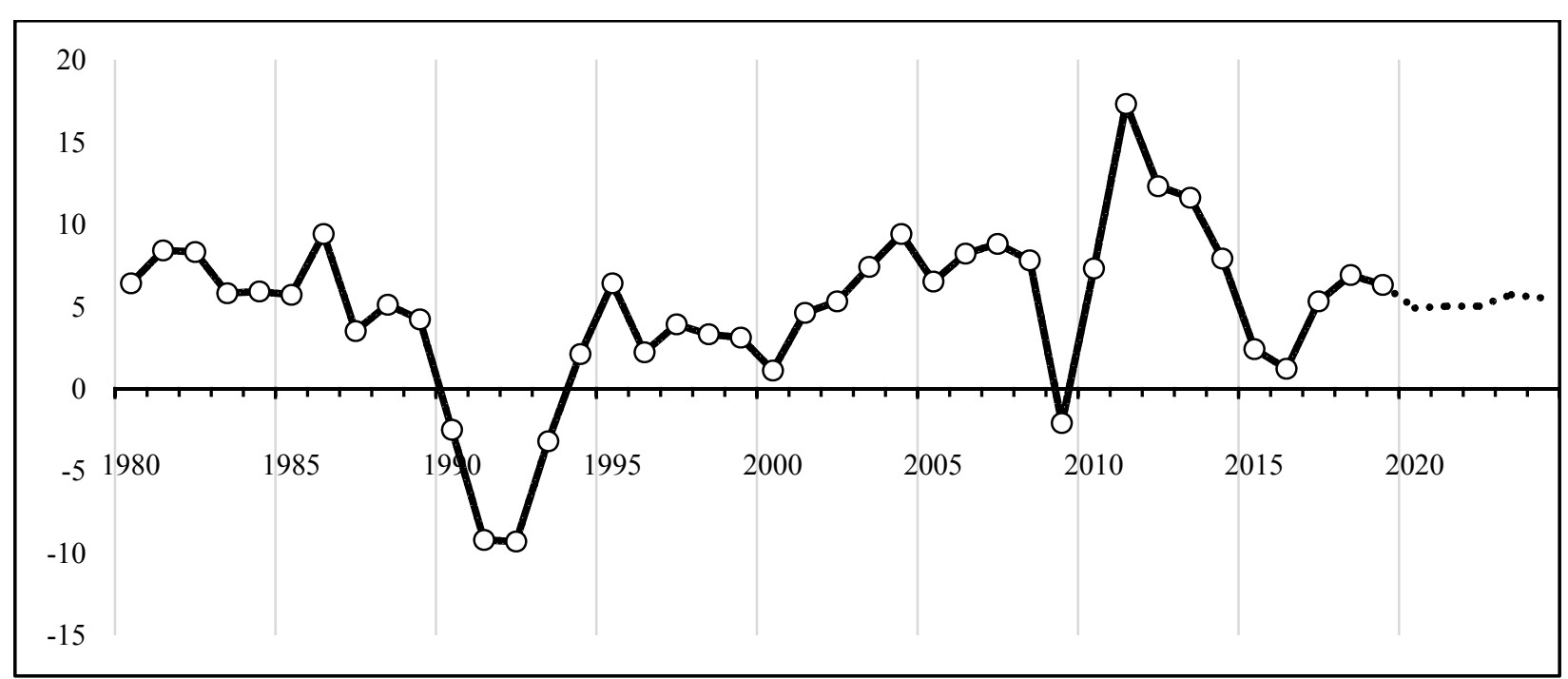

Figure 5. Trend of real GDP growth in Mongolia (annual percent change). Source: IMF Data Mapper, Country database (https://www.imf.org/external/datamapper).

The high growth, however, lasted for only short term. Mongolian economic condition (balance of payment and fiscal position) had been deteriorating until IMF Executive Board approved a three-year Extended Fund Facility (EFF) program in May 2017. In particular, government implemented expansionary fiscal policy and issued sovereign bonds in global financial markets to finance infrastructure projects and mortgage loan financing program, which were channeled through the Development Bank of Mongolia and Bank of Mongolia, which, in turn, led to increases in budget deficits, public debt, and decreases in economic growth (IMF, 2017). However, the fiscal deficit itself could be a misleading indicator, since it depends on the cases: if the fiscal deficit increases because of public investment activities that promise high returns in the future, sovereign risk spreads may decrease in the short run, and if the fiscal deficit increases because of higher government wage expenditures, spreads may increase (Akitoby \& Stratmann, 2008). More importantly, Akitoby and Stratmann 
(2008) examined the effect of fiscal policy on sovereign risk spreads and concluded that debt-financing spending increases sovereign risk, and alternatively, tax-financed spending lowers spreads.

Figure 6-1 shows the large increase in accumulated government debt (relative to GDP) due to the past policy errors (expansionary fiscal policies and sovereign bonds) implemented by government. As a result, the credit rating (sovereign rating) of Mongolian government was reduced by global credit rating agencies ${ }^{12}$, which reduced the foreign investors' confidence in Mongolia. El-Wassal (2013) implied that the stable macroeconomic environment is crucial for the development of stock market, since it leads to an increase in investor's confidence in the financial market. In addition, the past expansionary fiscal policies affected adversely the stock market in Mongolia in a different way. The government increased borrowing by issuing securities in domestic bond market over the past years, which, in turn, led to decreases in private sector investment. That means the crowding-out of the stock market that provides the capital resources for firms to implement productive investment projects.

The trends of government budget balance and government securities from 2010-2017 are illustrated in Figure 6-2. Government borrowing is considered basically as one of the fiscal policy tools to finance government expenditures and fiscal deficit. However, if government increases borrowing significantly during the economic recession, it would crowd out ${ }^{13}$ the private sector investment. This crowding-out effect is one of the shocks of macroeconomic policies that prevents the stock market from achieving its potential development. For instance, Figure 7-1 illustrates the trends of stocks traded value and government securities traded value during 2010-2017. The government borrowing (newly issued government bonds) was increased sharply from about 3 percent in 2011 to about 16 percent in 2016, while the stocks traded value continued to be stagnant during that period.

The crowding-out effect reduced not only private sector investments but long-term investments through capital resources in stock market. Additionally, the crowding-out effect leads to the higher interest rates, which, in turn, increase the borrowing costs (interest expense) for both government and private sector. Alternatively, central banks will have to tighten monetary policy by raising interest rates or reducing credit in the financial system in order to offset the impact of expansionary fiscal policy on aggregate demand and inflation in the economy (Hilbers, 2005).

It is also critical to analyze the impacts of monetary policy on the stock market. In Mongolia, the current policy rate ${ }^{14}$ of Bank of Mongolia is too high in comparison with Asian economies. Figure 7-2 illustrates the scatter plot between policy rates and financial markets index (IMF) among Asian economies. Based on the World Bank classification (by income), high-income economies represent the high level of financial market development in accordance with lower policy rates. But lower- and upper-middle income economies have low level of financial development with high policy rates. The high policy rates of central banks would increase the riskiness of stocks or cost of equity, and the investments in stock market would, therefore, be reduced.

\footnotetext{
12 Credit rating of Mongolia was reduced by Moody's from B1 (May 2014) to Caa1 (May 2017), https://www.moodys.com/credit-ratings/Mongolia-Government-of-credit-rating-806356900.

13 Increase in government spending may decrease the amount of private sector investment, which is known as "Crowding out" effect, https://www.economicshelp.org/blog/1013/economics/crowding-out/.

${ }_{14}$ In 2007, Central bank's bill rate (weighted average rate from 3 to 180 days) was introduced by Bank of Mongolia as an official interest rate (policy rate).
} 


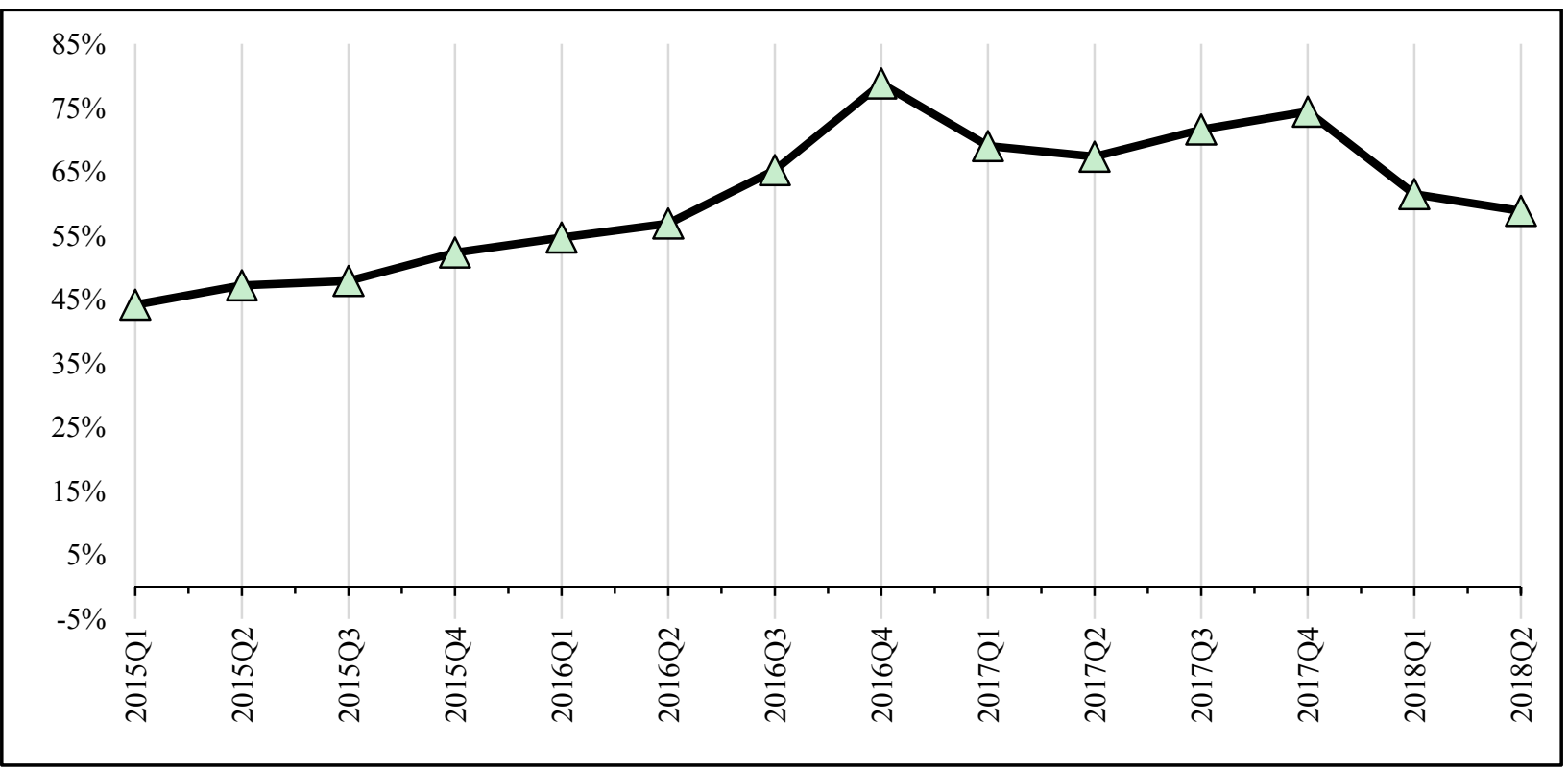

Figure 6-1. Government debt (external and domestic debt). Source: Statistical database of the Bank of Mongolia, (https://www.mongolbank.mn).

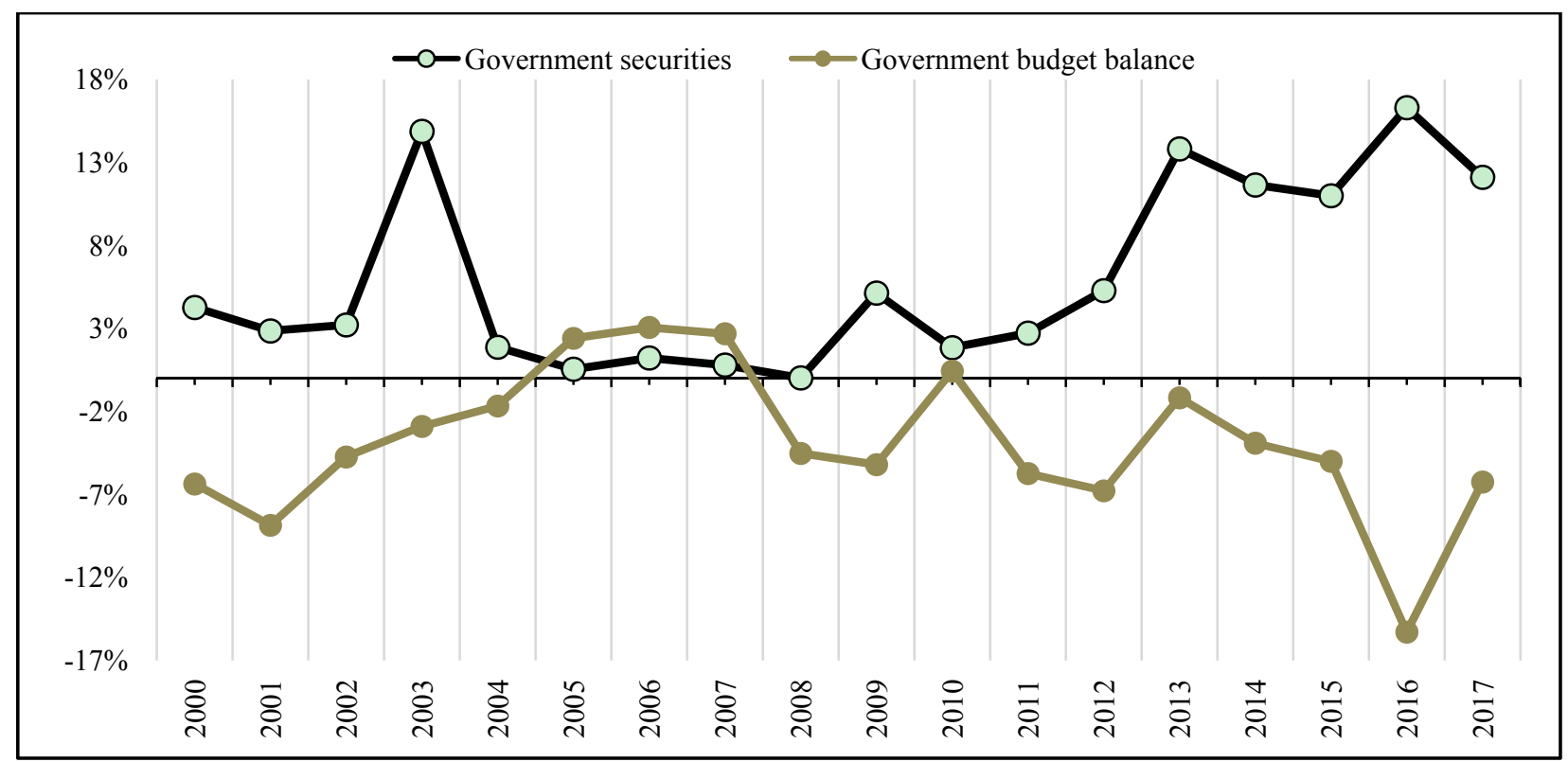

Figure 6-2. Government budget balance and government securities (domestic). Source: Based on the statistical database of the National Statistics Office of Mongolia, and Ministry of Finance.

Figure 6. Government debt, fiscal balance, government securities (\% of GDP).

According to Bernanke and Kuttner (2005), the changes in monetary policy are transmitted through the stock market via changes in the values of private portfolios (wealth effect), changes in the cost of capital and by other mechanisms as well. Basically, central banks in developing countries tend to implement tight or contractionary monetary policies to avoid their currency depreciation and high inflation rate. The high policy rate kept by Bank of Mongolia has also been inevitable because of the needs to cope with the decrease in foreign exchange reserves, exchange rate depreciation, and weakening balance of payment. Regarding the EFF 
program, the staff team of IMF in the staff report ${ }^{15}$ also recommended that monetary policy should remain prudent and appropriately tight for the time being until the economy normalized.

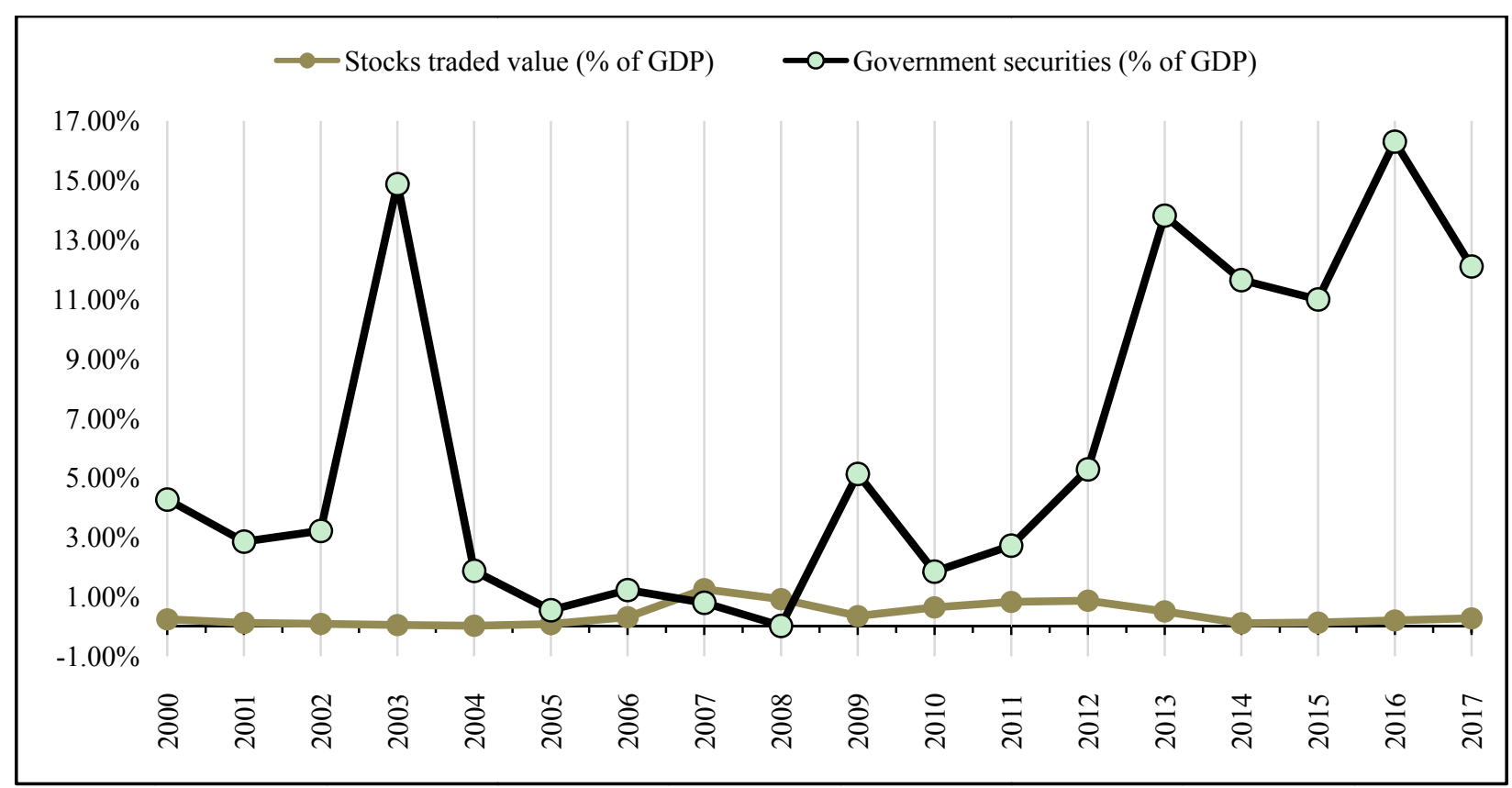

Figure 7-1. Stocks traded value and government securities traded value. Source: Statistical database of Financial Regulatory Commission, and Ministry of Finance.

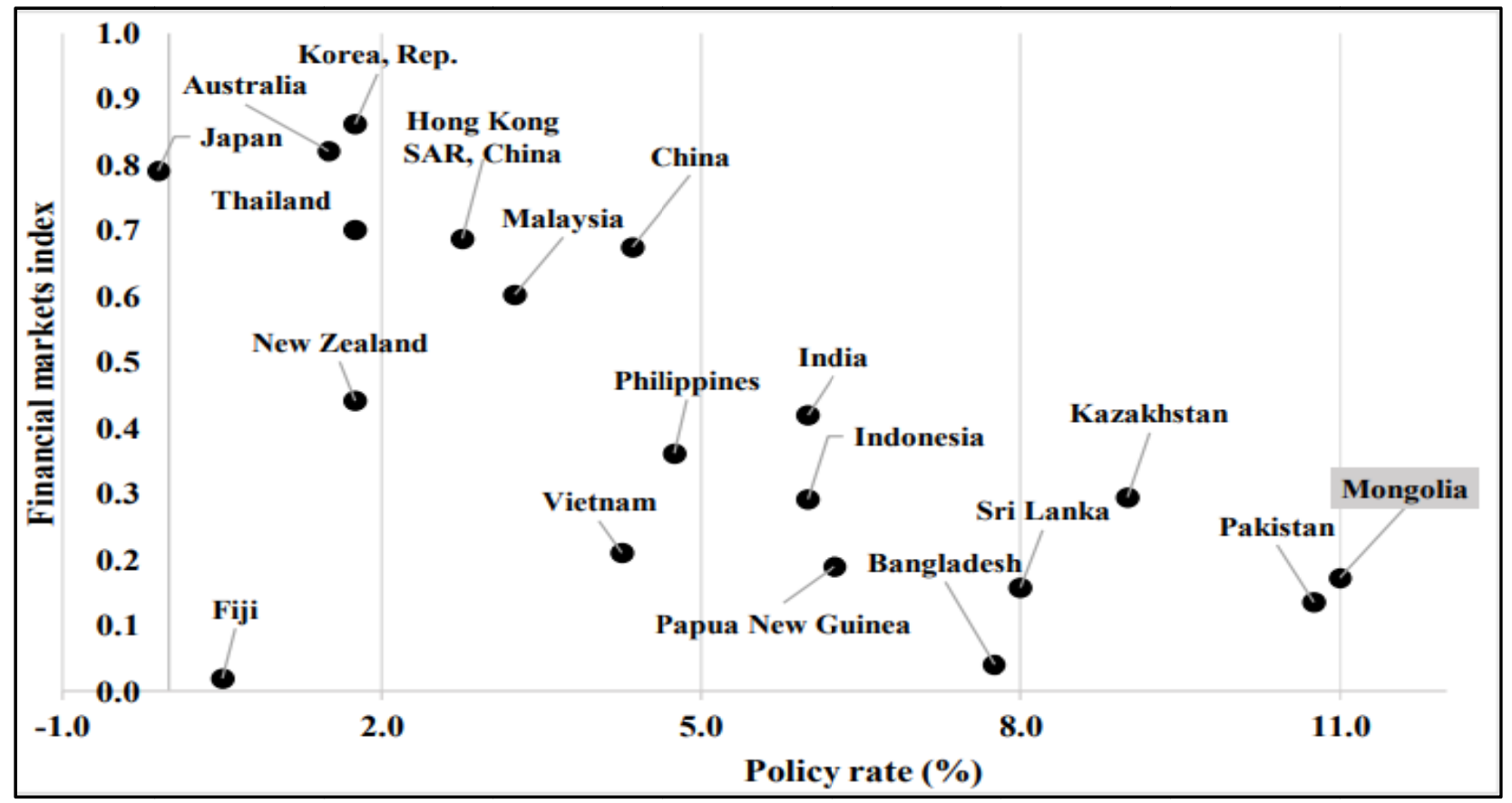

Figure 7-2. Policy rates and financial markets index (2016) among Asian economies. Source: IMF Financial Development Index Database (Excel), website: https://www.data.imf.org, and policy rates are retrieved from websites: http://www.cbrates.com/, https://www.global-rates.com/interest-rates/central-banks/central-banks.aspx.

Figure 7. Adverse impacts of macroeconomic policies on stock market.

$\overline{15}$ Staff report, IMF country report 17/140, see the website: https://www.imf.org/en/Countries/MNG. 
Bank of Mongolia has been keeping the high policy rate despite the lower inflation rate ${ }^{16}$ and strong economic recovery. For instance, during 2010-2017, annual policy rate, weighted average interbank rate, weighted average lending rate, government bonds' rate or yield (52 week) averaged 12.1\%, 12.0\%, 18.3\%, $13.8 \%$, respectively, based on the statistical database of Bank of Mongolia, and the stock market has been exposed significantly to the too high policy rate. The stock market response to monetary policy changes is well described by Bernanke and Kuttner (2005). Their paper ${ }^{17}$ implied that reaction of equity prices to monetary policy is, for the most part, not directly attributable to policy's effects on the real interest rate. Instead, the impact of monetary policy on stock prices seems to come either through its effects on expected future excess returns or on expected future dividends. They concluded that tight monetary policy lowers stock prices by raising the expected equity premium, which is broadly consistent with the predictions of the standard capital asset pricing model (CAPM). This monetary policy effect could come at least through two ways: first, tight money could increase the riskiness of stocks directly; second, tight money could reduce the willingness of stock investor to bear risk (excess sensitivity or overreaction of stock prices to monetary policy actions).

Regarding the shocks of fiscal policy and monetary policy on stock market, it is crucial to obtain the empirical evidence by conducting quantitative estimates in order to conclude whether stock market responds negatively to policy shocks or not. Thus, the ultimate objective of this study is to investigate or demonstrate the adverse impacts of fiscal policy and monetary policy on stock market in Mongolia, based on the two assumptions of policy actions, namely, crowding-out effect and high policy rate.

\section{Theoretical Framework}

This section focuses on a framework for development of stock markets, asset pricing model, and transmission mechanisms of monetary policy. As mentioned in the introduction, El-Wassal (2013) developed the fundamental framework for stock markets through constructing the "building block" and "supporting block" that affect substantially to the development level of stock markets. Building block comprises the supply factors: stage of economic development, economic size, and structure of economy; and demand factors: economic growth, high level of per capita GDP, investor base and institutional investors and portfolio cash flows.

These factors of building block indicate the importance of economic development for stock markets, which are basically base requirements for further development of stock market. Underdeveloped economies usually have a volatile investment environment, weak institutional and legal frameworks, poor governance, lack of transparency, low levels of per capita income, and usually characterized by price volatility, lack efficiency of scale, lower stock market turnover ratio (El-Wassal, 2013). The supporting block comprises the institutional factors: regulatory and legal framework, market infrastructure, banking sector development, political stability, financial literacy; and economic policies: monetary policy, fiscal policy and foreign participation policy. Regarding the institutional factors, weaknesses of institutional development of regulatory organization was already summarized in the introduction section of capital market in Mongolia. The basic hypothesis on the impacts of fiscal and monetary policy on stock market is based on the theoretical framework above developed by El-Wassal (2013).

\footnotetext{
${ }^{16}$ During 2015-2018, annual inflation rates were $1.9 \%, 1.1 \%, 6.4 \%, 8.1 \%$, respectively, see the website https://www.mongolbank.mn/eng/dblistcpi_mng.aspx?vYear=2017\&vMonth=.

17 Ben S. Bernanke and Kenneth N. Kuttner (2005). What explains the stock market's reaction to federal reserve policy? Journal of Finance, 60, 1221-1257.
} 
A widely-known assets pricing model, namely, capital asset pricing model (CAPM) is used for estimating an intrinsic value or cost of equity for publicly traded companies. $\mathrm{CAPM}^{18}$ describes the relationship between expected return and risk of investing in a security. The model indicates that the expected return on a security is equal to the risk-free return plus a risk premium, which is based on the beta of that security (a measure of non-diversifiable risk). The simple mathematical representation of CAPM is written as follows:

$$
E(R)_{p}=R_{f}+\beta_{p}\left[E(R)_{m}-R_{f}\right]
$$

where $E(R)_{p}$ is an expected return on security or portfolio; $R_{f}$ is a risk-free rate; $E(R)_{m}$ is an expected return on market index; $\beta_{p}$ is systematic risk of equity or portfolio; $\left[E(R)_{m}-R_{f}\right]$ is risk premium. Generally, an appropriate risk-free rate is considered by investors as a government bond yield. For instance, crowding-out effect reduces the private sector investment and increases interest expense or bond yield because of large amount of government borrowing funded through securities. In order to finance fiscal deficit during economic recession, government has to offer excess return or yield over policy rate of Central bank.

Broadly speaking, the yield curve of government bond is used as a benchmark for investors to allocate their investments in financial instruments which provide high investment returns. Thus, both high policy rate and risk-free rate affect the stock prices by increasing riskiness of stocks or reducing investors' willingness, which is consistent with the predictions of CAPM (Bernanke \& Kuttner, 2005).

The following theories on transmission mechanisms of monetary policy are based on the economics book $^{19}$ written by Mishkin (2016a).

First, Tobin's $q$ theory explains how monetary policy can affect the economy through its effects on the valuation of stocks. Tobin defines the $q$ as the market value of firms divided by replacement cost of capital. If $q$ is high, the market price of firms would be high relative to the replacement cost of capital. Then, firms can issue stock and buy a lot of new investment goods with only a small issue of stock. Tobin $q$ 's transmission mechanism is expressed as follows:

$$
r \downarrow \Rightarrow P_{S} \uparrow \Longrightarrow q \uparrow \Longrightarrow I \uparrow \Longrightarrow Y^{a d} \uparrow
$$

where $P_{S}$ is stock price, and lower interest rate makes stocks more attractive related to the bonds. In other words, the interest rate or yield to maturity is negatively related to the bond price. Higher stock price leads to a higher $q$ and higher investment $I$, eventually, increases the aggregate demand $Y^{\text {ad }}$.

Second theory is wealth effect, and its transmission mechanism is expressed as follows:

$$
r \downarrow \Rightarrow P_{S} \uparrow \Longrightarrow \text { wealth } \uparrow \Rightarrow I \uparrow \Longrightarrow Y^{\text {ad }} \uparrow
$$

If stock prices rise, then, consumer's financial wealth would increase. Thereby, individuals are more likely to increase their spending, which, ultimately, leads to an increase in aggregate demand.

Third theory is balance sheet channel. Monetary policy can affect the firms' (listed companies) balance sheets in several ways. If interest rate is too high, it would reduce the firm's net worth, which, in turn, leads to an adverse selection and moral hazard problems. The transmission mechanism is expressed as follows:

$$
\begin{gathered}
r \downarrow \Rightarrow P_{S} \uparrow \Longrightarrow \text { firm's net worth } \uparrow \Longrightarrow \text { adverse selection } \downarrow \\
\text { moral hazard } \downarrow \Rightarrow \text { lending } \uparrow \Longrightarrow I \uparrow \Longrightarrow Y^{\text {ad }} \uparrow
\end{gathered}
$$

If firms have lower collateral and equity ownership due to reduction in net worth, they are more likely to engage in risky projects, thereby, adverse selection and moral hazard problems will be grown.

\footnotetext{
18 A brief introduction of CAPM is retrieved from website https://corporatefinanceinstitute.com/.

19 The Economics of Money, Banking, and Financial Markets by Mishkin (2016).
} 
Fourth theory is cash flow channel, which is similar to the balance sheet channel. As result of easy monetary policy, the firms' cash flow would increase due to lower interest rate, and its transmission mechanism is expressed as follows:

$$
\begin{gathered}
r \downarrow \Rightarrow P_{S} \uparrow \Longrightarrow \text { firm's cash flow } \uparrow \Longrightarrow \text { adverse selection } \downarrow, \\
\text { moral hazard } \downarrow \Rightarrow \text { lending } \uparrow \Longrightarrow I \uparrow \Longrightarrow Y^{\text {ad }} \uparrow
\end{gathered}
$$

If firms have more liquidity because of increases in cash flows, which makes it easier for lenders to select the right firms with high collateral and high net worth. Thus, the elimination of adverse selection and moral hazard problems lead to an increase in credit lending, investment, and aggregate demand.

\section{Literature Review}

Literature section is divided into the following two sub-sections: role of stock markets in long-run economic growth, and impacts of fiscal policy and monetary policy on stock market. Levine (1991) implied that an extensive literature documents the role of financial markets in economic development. Levine and Zervos (1998) proved that both stock market liquidity and banking development positively predicted growth, capital accumulation, and productivity improvements, when entered together in regressions, even after controlling for economic and political factors. In addition, they concluded that financial markets provided important services for growth, and that stock markets provided different services from banks, which is consistent with broad views.

Arestis, Demetriades, and Luintel (2001) examined the relationship between stock market development and economic growth by utilizing time series methods and data from five developed countries and by controlling for the effects of the banking system and stock market volatility. Based on their estimation result, they concluded that although both banks and stock markets may be able to promote economic growth, the effects of the former are more powerful.

Hsing (2003) estimated the VAR model to quantify the relative importance of external debt, exchange rates, monetary policy, stock prices, and other selected variables when explaining output fluctuations in Brazil. In the estimation results, impulse response functions indicated that the shocks to interest rate, external debt, and inflation rate had an inverse impact on output, whereas the shocks to currency and stock prices have a positive effect on economic activity.

Enkhzaya and Dulguun (2012) investigated the role of financial intermediation in economy of Mongolia in terms of private credit by banks to GDP, stock market capitalization to GDP and FDI to GDP. In their empirical analysis, they used quarterly data from 2000 to 2011 and an autoregressive distributed-lagged model (ARDL), which is used widely for analyzing relationship between financial markets and economic growth. Their estimation results indicated that one unit increase in private credit by banks to GDP led to $0.2 \%$ increase in real GDP; one unit increase in stock market capitalization to GDP led to $0.05 \%$ increase in real GDP; and one unit increase in FDI to GDP increased real GDP by $0.09 \%$, respectively.

Myagmarsuren (2015) assessed the Mongolian financial system based on matrix of financial system characteristics developed by World Bank (2012). Based on the assessment result, he concluded that the depth, efficiency, and stability of banking industry in Mongolia is on the average line of low- and middle-income economies, and the access of banking industry is far above the average. On the other hand, his assessment showed that the depth, efficiency, stability, and access of non-bank financial industries such as capital market, insurance and microfinance in Mongolia is far behind the economies that have same income level. 
Sahay et al. (2015) conducted empirical analysis on the effect of financial development on economic growth by using new broad-based index of IMF (2015), and found that relationship between financial development and economic growth is bell-shaped based on a sample of 128 countries over 1980-2013. Their paper's analysis indicated that financial development increases growth, but the effects weaken at higher levels of financial development, and eventually become negative. However, they also mentioned that the bell-shaped relationship between growth and the financial development index pertains only to the depth components of the index, for both markets and institutions. In other words, this implied that those countries that may have reached the maximum benefits in terms of growth from deepening financial institutions and markets may still reap further growth benefits from better access. Regarding the bell-shaped relationship, their estimation suggested that financial development index between 0.45 and 0.7 (with 95 percent likelihood) could generate the largest cumulative growth returns. Based on the database of financial development index (2016), Mongolian financial development index is about 0.40 , which indicates that financial development has become closer to reach the left edge of bell-shape because of recent improvements in financial market (index was 0.33 in 2013). Furthermore, the financial market development is crucial for diversifying economy and contributing to sustainable economic growth in Mongolia, and its growth-generating effect is inevitable in upcoming years.

The second sub-section of literature focuses solely on the impacts of macroeconomic policies on stock market. Gan-Ochir and Batnyam (2008) investigated the impact of global financial crisis (2007-2008) on stock market in Mongolia by using simulation methodology and by developing Mongolian capital market model (MCMM). In their paper, they emphasized that global financial crisis would affect the stock market through direct and indirect ways. Regarding direct impact of financial crisis on domestic financial market, however, the impact on stock market is relatively low despite the compliance of international standard and improvement in legal environment of capital market. However, indirect impact of financial crisis transmitted through macroeconomic indicators is quite high, and quarterly capital inflow or indirect FDI would decrease in the short term due to adverse effect of global financial crisis. More critically, the indirect impact of financial crisis is expected to be high in the medium term. Since Mongolia is one of the resource-rich countries, most of fiscal revenue comes from mining sector, particularly, exports of gold, copper, coal, which, in turn, makes Mongolian economy too vulnerable to external shocks (decrease in commodity prices and slow growth in neighboring countries). Regarding the indirect impact of financial crisis on domestic stock market, which is transmitted through monetary policy and fiscal policy, their empirical analysis indicated that after eight quarters, one percent decrease in policy rate would increase TOP- 20 index $^{20}$ by $0.6 \%$ and stock market capitalization to GDP by $0.07 \%$, respectively. After five quarters, however, 10 percent increase in general government expenditure (not government securities) would increase TOP- 20 index by $0.03 \%$, stock market capitalization to GDP by $0.004 \%$, respectively. The last estimation result is quite contradictory to the predictions of this study, which is covered in the following sections.

Bernanke and Kuttner (2005) analyzed the impact of changes in monetary policy on stock prices, and found that, on average, a hypothetical unanticipated 25-basis-point cut in the Federal Funds rate target is associated about a $1 \%$ increase in broad stock indexes. In particular, they implied that the reaction of equity prices to monetary policy is, for the most part, not directly attributable to policy's effects on the real interest rate. Instead, the impact of monetary policy surprises on stock prices seems to come either through its effects

${ }^{20}$ Stock market index or benchmark of Mongolian stock exchange (MSE). 
on expected future excess returns or on expected future dividends.

Akitoby and Stratmann (2008) examined the effect of fiscal policy on sovereign risk spreads and investigated whether the inter-action of fiscal variables with political institutions affect financial markets. They used panel data from emerging market countries and found that revenue-based adjustment lowers spreads more than spending-based adjustment. Cuts in current spending lower spreads more than cuts in investment. Additionally, they showed that debt-financed spending increases sovereign risk, while tax-financed spending lowers spreads.

Hsing (2011) applied the GARCH (Generalized Autoregressive Conditional Heteroscedasticity) model, and demonstrated that Bulgarian stock market index is positively associated with real GDP, M2 to GDP ratio and U.S. stock market index, and is negatively influenced by the ratio of the government deficit to GDP, domestic real interest rate, BGN/USD exchange rate, expected inflation rate, and the euro area government bond yield. Based on estimation results, the paper implied that authorities may need to pursue or maintain economic growth with fiscal discipline, moderate increase in money supply, and relatively low interest rate or expected inflation rate.

Monetary policy division of Bank of Mongolia (2010) investigated the determinants of interest rate, and emphasized that the interest rate is affected by the following five factors: macroeconomic condition, financial intermediation (direct finance), domestic and foreign resources in terms of bank deposits, development of banking industry and infrastructure development of financial system. Regarding the financial intermediation, monetary policy division implied that monetary policy is channeled through financial market or monetary policy transmission mechanism, and thus the financial market development is crucial element for successful monetary policy. More critically, the policy division's paper indicated that capital market development reduces the importance of indirect finance. If the size of banking industry in financial market is relatively large, then, it would become one of the reasons that commercial banks keep high interest rate in order to increase their profits (interest revenue). In general, banks reduce transaction costs in terms of asymmetric information, adverse selection, and moral hazard. Alternatively, capital markets increase direct finance, and at the same time reduce the borrowers' dependence on intermediation of banking industry. Specifically, high level of capital market development provides the wide range of financial products for borrowers, lenders, and investors, which, in turn, leads to inverse flows of funds from banking industry (short-term financing) to capital market (long-term financing).

Taguchi and Enkhbaatar (2019) investigated the relationship between stock market and macroeconomic policies in Mongolia under the hypothesis that recent biases of fiscal and monetary policies would distort her stock-price formation. The empirical results indicated that cumulative public debt and too high policy rate have stagnated the stock prices, through identifying the negative impulse responses of stock prices to the shocks of policy rate and government securities under a vector-autoregressive model estimation. In addition, the paper suggested that strategic policy implication for normalizing the stock prices could be the significance in ensuring budget consolidation, and in addressing a fear of floating in monetary policy management in Mongolia.

This study's contribution in the literature reviewed above is to enrich the evidence of the effects of macroeconomic policies on the stock market development in Mongolia. To be specific, the study aims to investigate the adverse impacts of fiscal policy and monetary policy on stock market in Mongolia, based on the two assumptions of policy actions, namely, crowding-out effect and high policy rate. 


\section{Empirics}

According to the extensive literature, many factors affect the stock market by either direct way or indirect way. This section conducts the quantitative estimation of impact of fiscal policy and monetary policy on stock market in Mongoliaby applying a VAR model. The main prediction of this study is the crowding-out effect and high policy rate would lower stock price and stocks traded value by reducing private sector investment and increasing riskiness of stock or excess return. The section starts from identifying key variables, data, and methodology for a VAR estimation, and then discusses the estimation results.

\section{Data and Methodology}

The study identifies following six variables for VAR estimation, namely, stock price (SP), stocks traded value (STV), policy rate (IR), money supply (M2), government securities traded value (GSV), and Gross Domestic Product (GDP). The sample comprises monthly data over the period January 2003 to December 2017.

First variable and second variable, the stock price (SP) and stocks traded value (STV), are retrieved from statistical database of National Statistics Office of Mongolia (NSO). Stock price (SP) is represented by the stock market index (TOP-20 index) of Mongolian stock exchange (MSE), and its data trend is illustrated in Figure 8-1. Stocks traded value (STV) is expressed in billions of national currency (MNT). The main hypothesis of study predicts that stock price (SP) and stocks traded value (STV) respond negatively to policy shocks: the fiscal crowding-out and high policy rate.

Third variable and fourth variable, the policy rate (IR) and money supply (M2), are retrieved from statistical database of Bank of Mongolia. Money supply (M2) is expressed in billions of MNT, which is showed in Figure 8-2. Increase in money supply (M2) is expected to stimulate the stock price and stocks traded value due to an increase in credit. The policy rate (IR) is expressed in monthly percent rate, and this rate is Central bank's weighted average bill rate from 3 to 180 days, which was introduced by Bank of Mongolia in 2007 as an official policy rate. As noted in the introduction, the policy rate is too high in Mongolia compared to Asian economies (Figure 7-2). Following the recent economic recession, Bank of Mongolia conducted tight monetary policy by increasing interest rates in order to protect from further currency depreciation and high inflation. Despite some improvementin economic recovery in terms of real GDP growth and efficiency of fiscal policy actions, Bank of Mongolia has been keeping high policy rate and increased it by 100 basis points (bps) from $10 \%$ in first quarter of 2018 to $11 \%$ in fourth quarter of 2018 . Regarding the high policy rate kept by Bank of Mongolia, the study predicts that tight monetary policy would lower the stock price. Figure 8-3 illustrates the trends of policy rate (IR) and inflation rate during the estimation period.

Fifth variable, the government securities traded value (GSV) is another key policy variable and is expressed in billions of MNT, which is retrieved from the statistics of Ministry of Finance (MOF). As noted in the introduction, crowding-out effect lowers the stock price by reducing private investments, capital resources in stock market, which, in turn, leads to an increase in borrowing cost or government bond yield because of large amount of government borrowing. Thus, central banks typically respond to this crowding-out effect by conducting tight monetary policy or increasing interest rates. Regarding the crowding-out effect, Figure 8-4 illustrates the trends of government securities traded value (GSV) and stocks traded value (STV), respectively. The last variable, GDP, is retrieved from statistical database of National Statistics Office of Mongolia, and is used as a control variable to set aside the effects of economy on stock market. GDP is converted to seasonally adjusted time series data. 
For purposes of analyzing dynamic impact of policy changes, the vector autoregressive model (VAR) is applied for investigating the responses of stock price (SP) and stocks traded value (STV) to the structural shocks of fiscal and monetary policy. The VAR model is the system equation of lagged values of the endogenous variables, which is widely used for forecasting dynamic impact of interrelated time series and for tracing the structural shocks of changes in macroeconomic policies. The mathematical representation of VAR is expressed as follows:

$$
y_{t}=\gamma+A_{1} y_{t-1}+\cdots+A_{j} y_{t-j}+K x_{t}+u_{t}(1)
$$

where $y_{t}$ is a vector of the endogenous variables, whereas $x_{t}$ is a vector of the exogenous variables in the system equation; $\gamma$ is a constant vector; $A_{1}, A_{j}$ and $K$ are matrices of coefficient; $y_{t-j}$ is a vector of lagged endogenous variables; $u_{t}$ is a vector of error terms or innovations in the system equation, which is basically contemporaneously correlated but not correlated with its own lagged values and right-hand side endogenous variables. Furthermore, the five endogenous variables and one exogenous variable, namely, stock price (SP), stocks traded value (STV), policy rate (IR), money supply (M2), government securities traded value (GSV), and GDP as a control variable in the VAR system equation could be rewritten as follows:

$$
S M_{t}=\lambda_{i} S M_{t-i}+\delta_{j} P S_{t-j}+c_{1}+u_{1 t}
$$

where $S M$ is the mix of stock market indicators, which comprises the endogenous variables of stock price (SP), stocks traded value (STV); PS is the policy shocks which comprise the endogenous variables of policy rate (IR), money supply (M2), government securities traded value (GSV); whereas $c_{1}$ is the control variable of GDP. The lag interval of 1 is selected for VAR model estimation based on the Schwarz information criterion (SC) with maximum lag interval of 3. In addition to forecasting the macroeconomic activities, VAR model is used for two primary functions: testing Granger causality and studying the effects of policy changes through impulse response functions (Greene, 2003). The study focuses solely on the impulse response functions and investigates the responses of stock price (SP), stocks traded value (STV) to structural shocks of fiscal policy and monetary policy (IR, M2, GSV) based on the reduced VAR model (2).

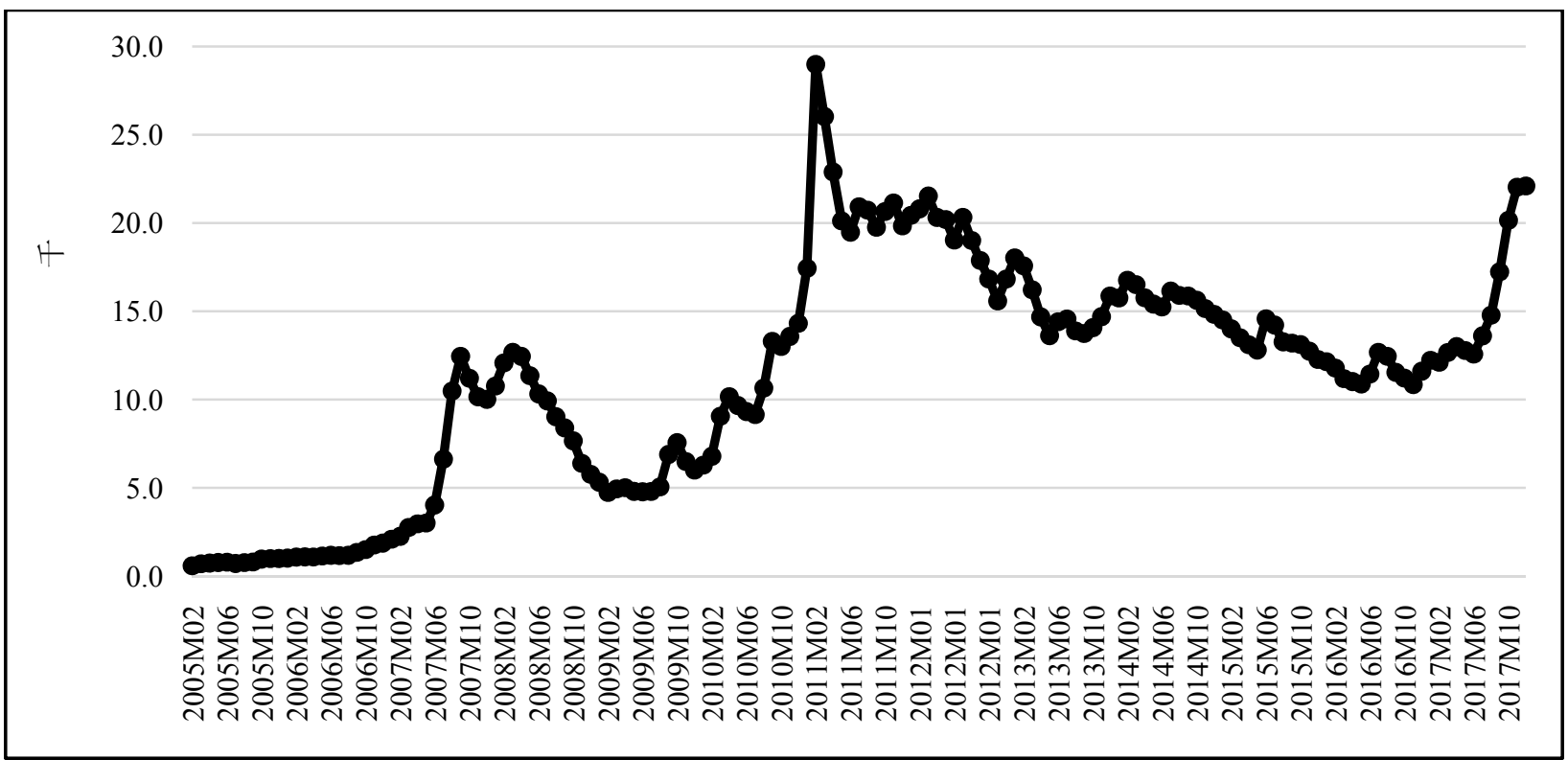

Figure 8-1. Stock price (SP) or TOP-20 index of Mongolian stock exchange. Source: Statistical database of National Statistics Office of Mongolia. 


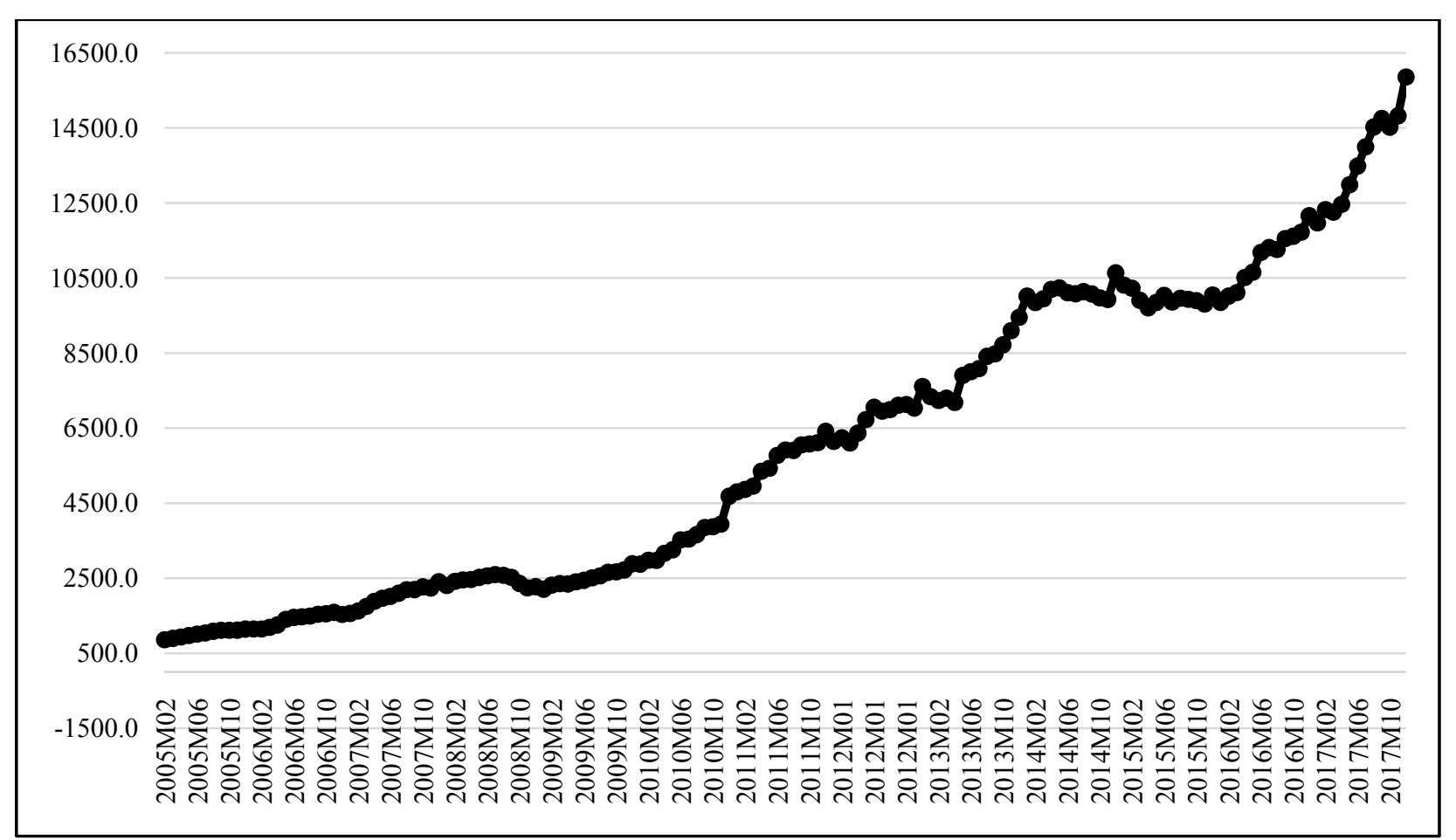

Figure 8-2. Money Supply (M2), /MNT billions/. Source: Statistical database of Bank of Mongolia.

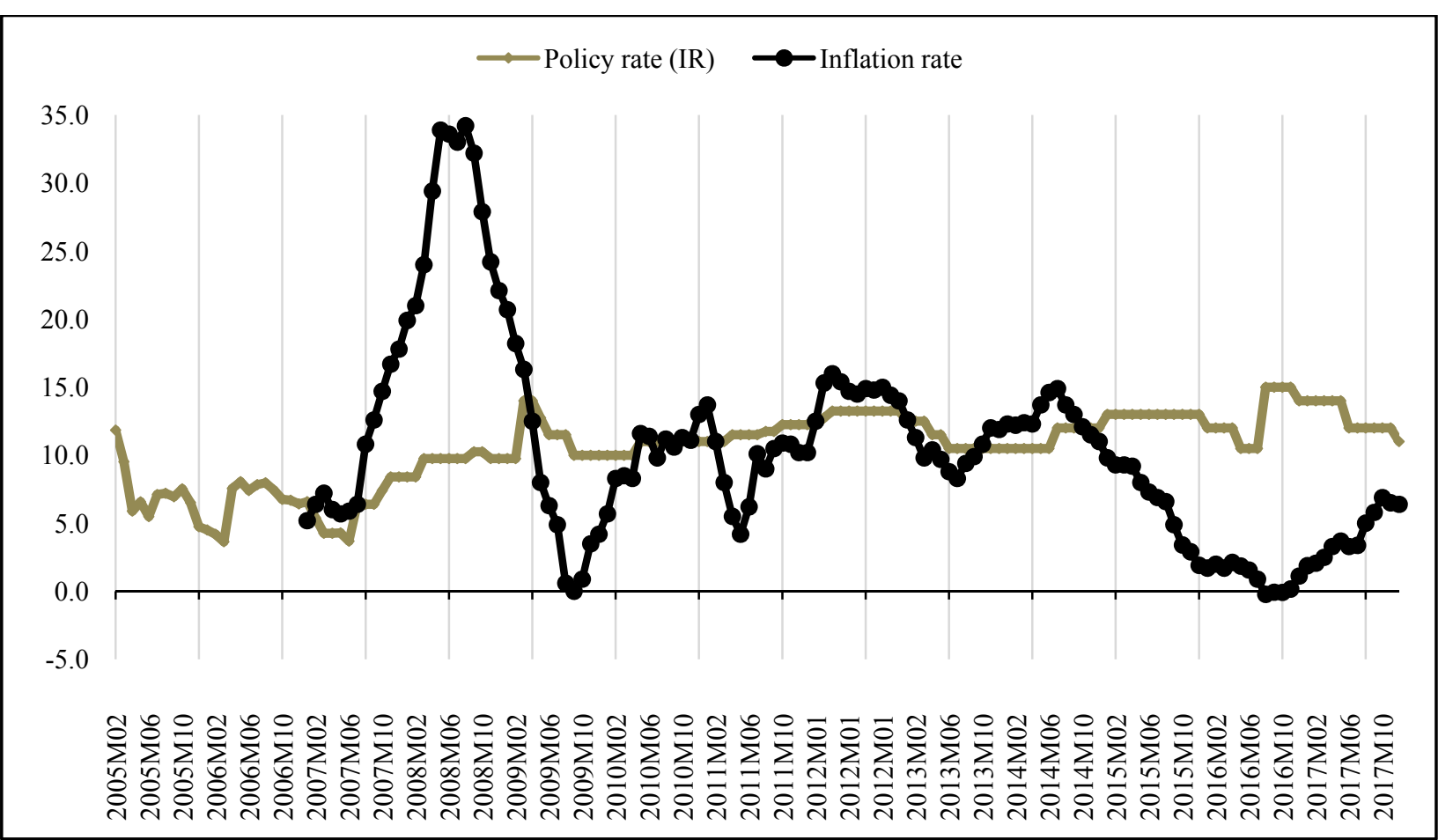

Figure 8-3. Policy Rate (IR) and Inflation Rate (CPI), /Monthly Percent Change/. Source: Statistical database of Bank of Mongolia. 


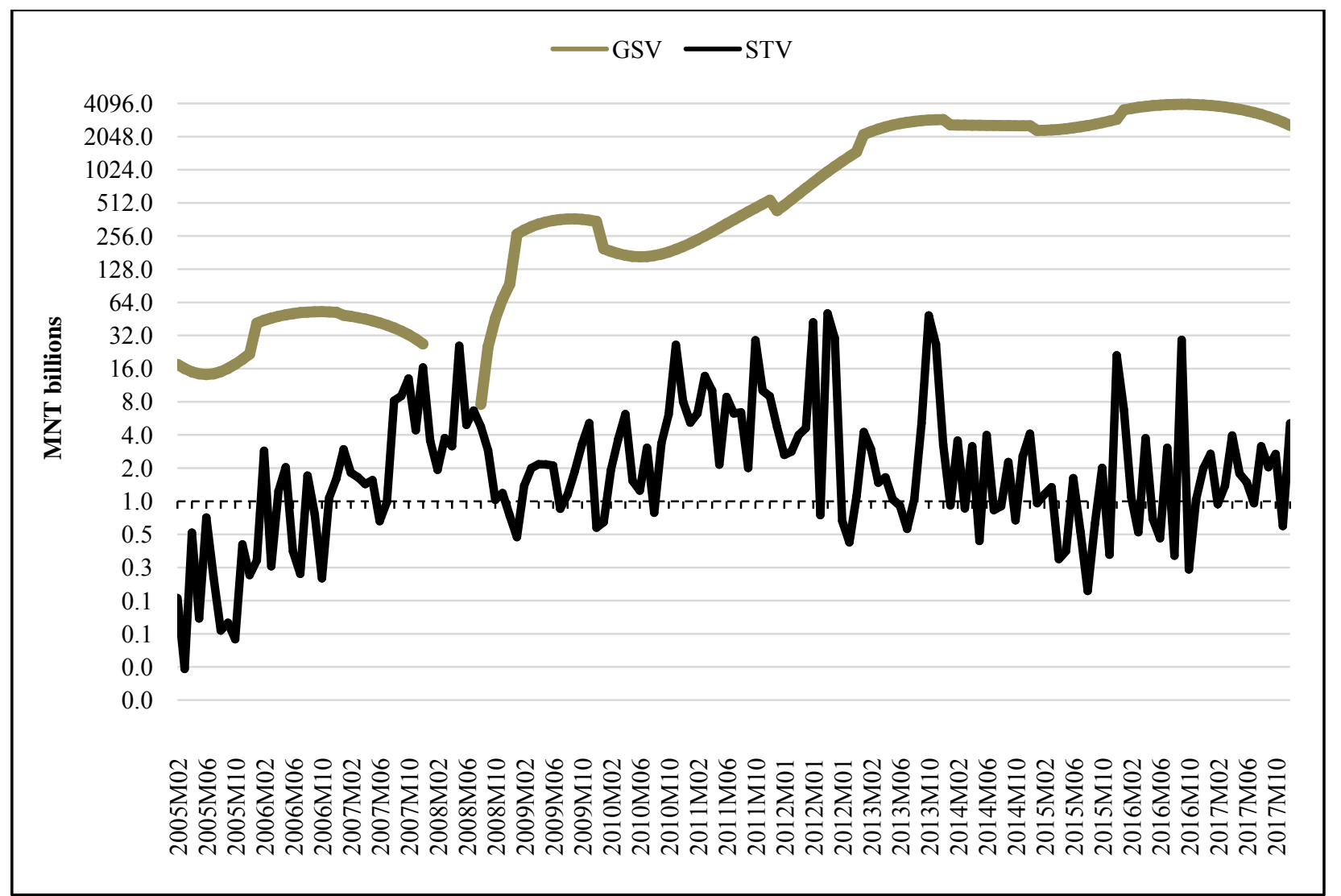

Figure 8-4. Government Securities Traded Value (GSV) and Stocks Traded Value (STV). Source: Statistical database Ministry of Finance and Bank of Mongolia.

Figure 8. Data observation for VAR estimation variables.

The reduced VAR model (2) is an appropriate approach for this study, which aims to investigate the short-term dynamic impacts of policy shocks rather than long-term relationship. The time-series analysis usually requires the unit root test, and processes the level data with unit root into differentiated ones for to ensure the stationarity of data property. In this study, however, the non-differentiated data are used for VAR model estimation. Hamilton (1994) implied that the level form is the best in running VAR models because differencing may throw away valuable information in the times series data. For purposes of tracing the impact of one-time shock to the error term of policy variables, the study applies the recursive Cholesky or thogonalization as one of the short-term restrictions in order to identify properly structural shocks in the VAR estimation. The innovations or error terms of endogenous variables in VAR model are contemporaneously correlated. By imposing the Cholesky restriction, the error term of reduced VAR model could be linked with the structural shock of the policy variables (Taguchi \& Enkhbaatar, 2019). Thus, the following recursive orders are imposed by Cholesky restriction: from policy variables (IR, M2, GSV) to stock market indicators (SP, STV).

\section{Estimation Results and Discussion}

Table 5-1, Table 5-2, and Figure 9-1, Figure 9-2 indicate the estimated outcomes of VAR model and impulse responses of stock price (SP), stocks traded value (STV) to policy shocks, respectively. 
Table 5-1

Result of Estimated VAR Model

\begin{tabular}{llllll}
\hline & IR & M2 & GSV & SP & STV \\
\hline IR(-1) & $0.847^{* * *}$ & $-0.002^{*}$ & $-0.019^{* * *}$ & $-0.007^{* *}$ & $-0.093^{* *}$ \\
& {$[20.084]$} & {$[-1.697]$} & {$[-2.767]$} & {$[-2.055]$} & {$[-2.579]$} \\
M2(-1) & 0.888 & $0.929^{* * *}$ & $-0.487^{* *}$ & $0.252^{* * *}$ & 0.358 \\
& {$[0.672]$} & {$[29.506]$} & {$[-2.298]$} & {$[2.326]$} & {$[0.318]$} \\
GSV(-1) & $0.179^{*}$ & 0.004 & $0.995^{* * *}$ & $-0.014^{*}$ & $-0.245^{* * *}$ \\
& {$[1.672]$} & {$[1.461]$} & {$[58.008]$} & {$[-1.653]$} & {$[-2.692]$} \\
SP(-1) & 0.338 & -0.002 & $0.113 * * *$ & $0.969^{* * *}$ & $1.240^{* * *}$ \\
& {$[1.422]$} & {$[-0.426]$} & {$[2.964]$} & {$[49.689]$} & {$[6.122]$} \\
STV(-1) & -0.044 & 0.003 & -0.003 & 0.005 & $0.157^{* *}$ \\
& {$[-0.485]$} & {$[1.406]$} & {$[-0.211]$} & {$[0.687]$} & {$[2.033]$} \\
Const. & 1.831 & $0.070^{*}$ & $-0.495^{*}$ & 0.123 & $-7.784^{* * *}$ \\
& {$[1.074]$} & {$[1.734]$} & {$[-1.811]$} & {$[0.883]$} & {$[-5.364]$} \\
GDP & -1.478 & $0.071^{*}$ & $0.483 *$ & $-0.224^{*}$ & -0.439 \\
Adj. R & {$[-0.957]$} & {$[1.937]$} & {$[1.953]$} & {$[-1.773]$} & {$[-0.334]$} \\
Sample size & 0.803 & 0.999 & 0.988 & 0.993 & 0.640
\end{tabular}

Notes. $* * * * *, *$ denote rejection of null hypothesis at the $99 \%, 95 \%, 90 \%$ level of significance, respectively. The value in [ ] are $t$-statistics.

Table 5-2

Impulse Responses of Stock Price (SP) and Stocks Traded Value (STV) to Policy Variables' Shocks

\begin{tabular}{|c|c|c|c|c|c|c|}
\hline \multicolumn{4}{|c|}{ Stock Price (SP) } & \multicolumn{3}{|c|}{ Stocks Traded Value (STV) } \\
\hline & IR & M2 & GSV & IR & M2 & GSV \\
\hline 1 & -0.02 & 0.01 & -0.02 & -0.09 & $0.22 * *$ & 0.02 \\
\hline 2 & -0.04 & 0.03 & -0.04 & -0.23 & $0.29 * *$ & -0.05 \\
\hline 3 & -0.07 & 0.06 & -0.06 & $-0.37 * *$ & $0.35 * *$ & -0.14 \\
\hline 4 & -0.11 & 0.10 & -0.09 & $-0.51 * *$ & $0.41 * *$ & -0.23 \\
\hline 5 & -0.16 & 0.14 & -0.12 & $-0.63 * *$ & $0.49 * *$ & $-0.33 * *$ \\
\hline 6 & $-0.21 * *$ & $0.18 * *$ & $-0.15 * *$ & $-0.73 * *$ & $0.57 * *$ & $-0.44 * *$ \\
\hline 7 & $-0.26 * *$ & $0.24 * *$ & $-0.19 * *$ & $-0.83 * *$ & $0.67 * *$ & $-0.55 * *$ \\
\hline 8 & $-0.31 * *$ & $0.29 * *$ & $-0.22 * *$ & $-0.92 * *$ & $0.77 * *$ & $-0.66^{* *}$ \\
\hline 9 & $-0.37 * *$ & $0.35 * *$ & $-0.26 * *$ & $-0.99 * *$ & $0.88 * *$ & $-0.77 * *$ \\
\hline 10 & $-0.42 * *$ & $0.42 * *$ & $-0.30 * *$ & $-1.06^{* *}$ & $1.00 * *$ & $-0.88 * *$ \\
\hline 11 & $-0.48^{* *}$ & $0.48 * *$ & $-0.34 * *$ & $-1.12 * *$ & $1.12 * *$ & $-1.00 * *$ \\
\hline 12 & $-0.53 * *$ & $0.55^{* *}$ & $-0.39 * *$ & $-1.18 * *$ & $1.24 * *$ & $-1.11 * *$ \\
\hline 13 & $-0.59 * *$ & $0.63 * *$ & $-0.43 * *$ & -1.22 & $1.37 * *$ & $-1.23 * *$ \\
\hline 14 & $-0.64 * *$ & $0.70 * *$ & $-0.48 * *$ & -1.26 & $1.51 * *$ & $-1.34 * *$ \\
\hline 15 & $-0.69 * *$ & $0.78 * *$ & $-0.53 * *$ & -1.29 & $1.64 * *$ & $-1.45 * *$ \\
\hline 16 & -0.74 & $0.85^{* *}$ & $-0.58 * *$ & -1.32 & $1.78 * *$ & $-1.57 * *$ \\
\hline 17 & -0.79 & $0.93 * *$ & $-0.63 * *$ & -1.34 & $1.92 * *$ & $-1.68 * *$ \\
\hline 18 & -0.84 & $1.01 * *$ & $-0.68 * *$ & -1.36 & $2.05 * *$ & $-1.78 * *$ \\
\hline 19 & -0.88 & $1.09 * *$ & $-0.73 * *$ & -1.37 & $2.19 * *$ & $-1.89 * *$ \\
\hline 20 & -0.92 & $1.17 * *$ & $-0.78 * *$ & -1.38 & $2.33 * *$ & $-1.99 * *$ \\
\hline 21 & -0.96 & $1.25 * *$ & $-0.83 * *$ & -1.38 & $2.47 * *$ & $-2.09 * *$ \\
\hline 22 & -0.99 & $1.33 * *$ & $-0.88 * *$ & -1.38 & $2.60 * *$ & $-2.19 * *$ \\
\hline 23 & -1.02 & $1.41 * *$ & $-0.93 * *$ & -1.37 & $2.73 * *$ & $-2.28 * *$ \\
\hline 24 & -1.05 & $1.49 * *$ & $-0.98 * *$ & -1.37 & $2.86^{* *}$ & $-2.37 * *$ \\
\hline
\end{tabular}

Note. $* *$ denotes rejection of null hypothesis at the $95 \%$ level of significance. Cholesky Ordering: IR M2 GSV SP STV. 

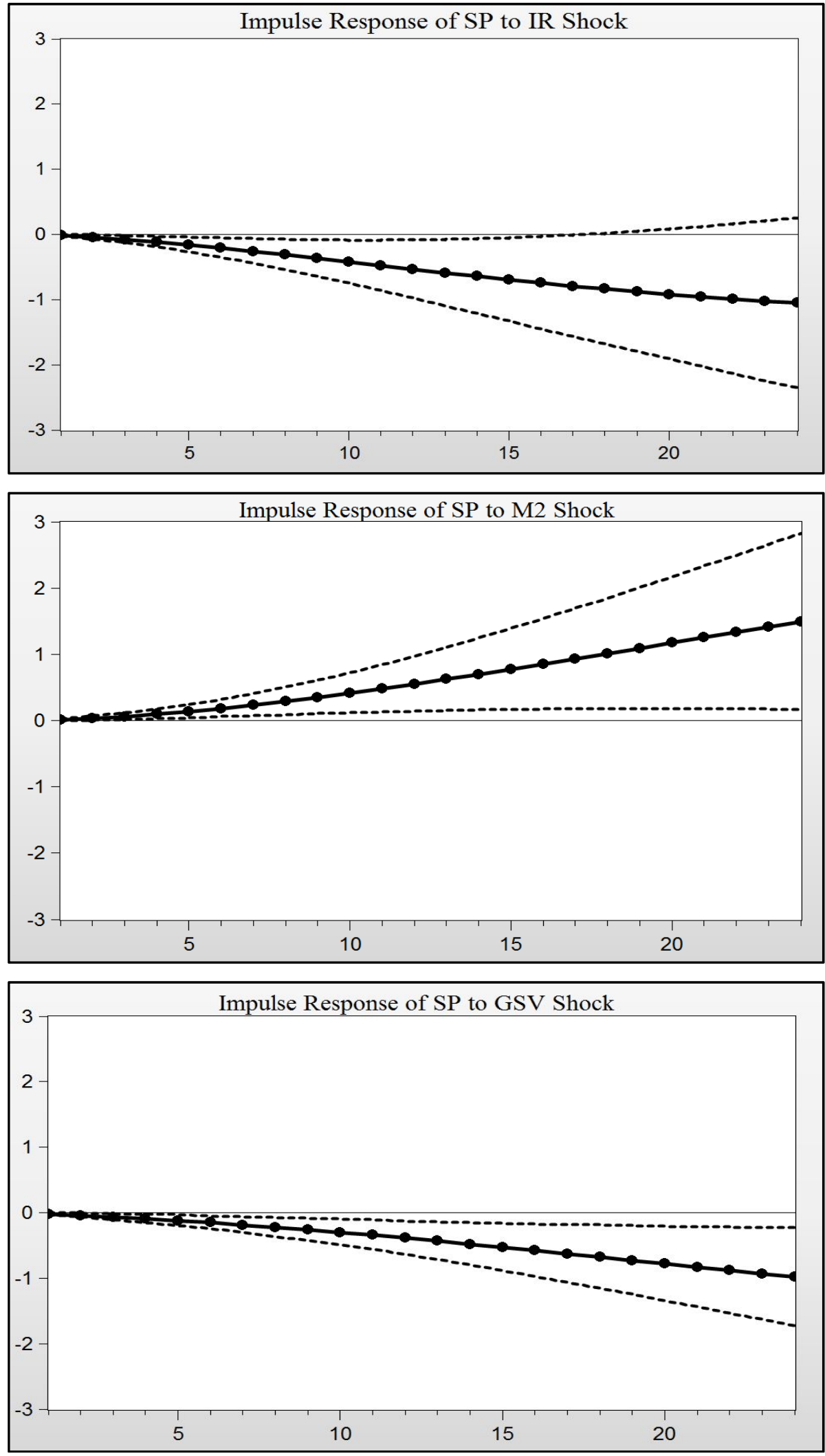

Figure 9-1. Impulse responses of Stock Price (SP) to policy variables' shocks. Note: The fine and coarse dotted lines denote the $95 \%$ error band over 24 -month period. 

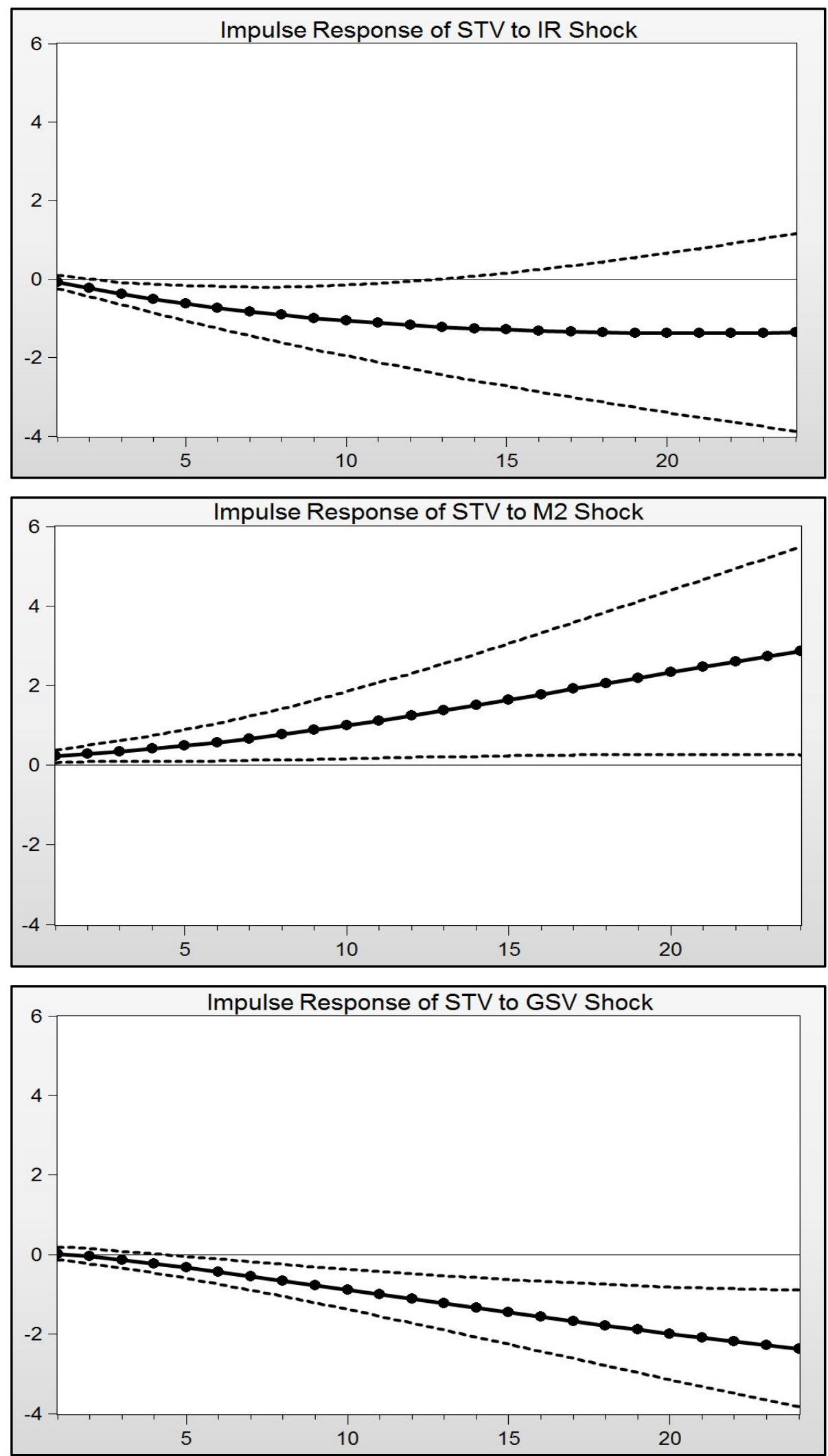

Figure 9-2. Impulse responses of Stocks Traded Value (STV) to policy variables' shocks. Note: The fine and coarse dotted lines denote the $95 \%$ error band over 24 -month period. 
As shown in Figure 9-1, the impulse response functions are reported for 24-month period and indicate that responses of SP (stock price) to policy shocks are statistically significant with a 95 percent of confidence interval. Particularly, SP responds negatively to the shock of policy rate (IR) from 6th month to 15th month, and to the shock of government securities traded value (GSV) from 6th month to 24th month, respectively. Regarding the shock of money supply (M2), SP responds positively from 6th month to last month. Figure 9-2 reports the impulse response functions of STV to policy shocks. STV responds negatively to the shock of IR from 3rd month to 12th month and to the GSV shock from 5th month to 24th month, respectively. Also, STV responds positively to the M2 from 1st month to last month.

As noted in the introduction and theoretical framework, the main predictions of this study were that the crowding-out effect and too high policy rate would lower the stock price and stocks traded value by reducing the private investment and increasing the riskiness of stocks or reducing the firms' net worth, cash flows. Regarding the VAR model estimation, both impulse response functions of stock market indicators demonstrate that stock market responds negatively to the shocks of policy rate and government securities, and responds positively to the shock of money supply, respectively.

Thus, the stock market development depends largely on the recent adverse impacts of fiscal policy and monetary policy. When a crowding-out effect is considered as fiscal policy bias, it is critical for government to avoidthe cost-inefficient expansionary fiscal policy and high level of sovereign debt. To lower the negative effects on stock market, government should reduce the accumulated government debt and obtain the normalization of domestic bond yield by increasing tax-based financing rather than government debt financing. Furthermore, government needs to keep maintaining fiscal consolidation, fiscal discipline, and debt management plan, and to avoid the politically affected policies without considering the long-term consequences.

Regarding the monetary policy, recently, Bank of Mongolia increased the policy rate by 100 bps due to accelerating growth in credit and imports. In comparison with other Asian economies, the current policy rate $(11 \%)$ is too high as showed in Figure 7-2. There are several factors to explain that Bank of Mongolia had to keep the high policy rate over the past decade. First, the expansionary fiscal policy and high level of sovereign debt affected the policy rates through stimulating the inflation and aggregate demand during the economic peak or boom cycle of commodity markets. As a response, Bank of Mongolia immediately conducted tight monetary policy by increasing policy rate. Alternatively, Mishkin (2016c) implied that governments in emerging market economies force domestic banks to purchase government bonds, when they face large fiscal imbalances and cannot finance their debt, which, in turn, leads to a weakening of the banking system, a worsening of adverse selection and moral hazard problems and a reduction of lending.

Second, the monetary policy is too sensitive to the external shocks of global commodity markets which basically deteriorates the balance of payment, foreign currency reserve, exchange rate, and eventually the banking system. To prevent the high inflation and exchange rate depreciation, Bank of Mongolia has been conducting tight monetary policy and keeping high policy rate based on the macroeconomic condition. On the other hand, Mongolian economy is heavily dependent on the mining sector and government's budget revenue comes from mostly exports of gold, copper, coal and other minerals. During the boom in economic and commodity markets, Bank of Mongolia engaged in quasi-fiscal activities by channeling the government's infrastructure spending and mortgage loan financing program, and even eased monetary policy, which, in turn, stimulated the credit growth and imports. According to the Calvo and Reinhart (2000), in many commodity 
exporting countries, commodity prices which drive the fluctuations in terms of tradeare far more volatile than exchange rate, and monetary authorities usually aims at smoothing exchange rate fluctuations, though. At the beginning of the economic contraction, Bank of Mongolia began increasing the policy rate steadily through pro-cyclical monetary policy in order to prevent further exchange rate fluctuations.

Third, monetary policy divisionof Bank of Mongolia (2010) clarified the interest rate determinants in Mongolia: macroeconomic condition, financial intermediation, domestic and foreign resources in terms of bank deposits, development of banking industry and infrastructure development of financial system. As noted in the introduction, the development level of banking industry is much higher than capital market in Mongolia. The financial intermediation in terms of direct finance is, however, an important factor for reducing the interest rate, because direct finance or long-term investment channeled through capital market can eliminate the adverse selection and moral hazard problems. In Mongolia, only 0.8 percent or 23,272 of total deposit holders $(2,901,242)$ own the 67.8 percent of total time deposits in the banking industry as a whole, according to the statistics of Bank of Mongolia (2017). In other words, this is the one of the many reasons that too high policy rate is not only the results of severe macroeconomic condition or external shocks.

As for monetary policy, monetary authority should obtain the benchmark policy rate among Asian economies in order to reduce the adverse impact on stock market in Mongolia. The high level of stock market development plays important role in financial system through reducing the adverse selection and moral hazard problems and providing the long-term investment and capital resources for sustainable economic growth. To enhance the stock market activity, monetary authority further needs to focus on the macro prudent monetary policy which is consistent with fiscal policy and to address the critical factors affecting the too high policy rate in Mongolia such as macroeconomic condition, balance of payment, exchange rate fluctuations, financial intermediation in terms of direct finance and imbalances of deposit holders base.

\section{Concluding Remarks}

According to the extensive literature, many factors affect the stock market by either direct way or indirect way. This study aims to investigate the adverse impacts of fiscal policy and monetary policy on stock market in Mongolia by using monthly data over the period January 2003 to December 2017 and applying a VAR model, with the predictions that both crowding-out effect and too high policy rate would lower the stock price and stocks traded value. The empirical analysis in this study indicated that stock price and stocks traded value responds negatively to the shocks of policy rate and government securities traded value, respectively. In other words, the accumulated government debt and too high policy rate have crowded out the private investments in stock market and lowered the stock price by increasing riskiness of stocks or reducing the firms' net worth, which are consistent with the main predictions of this study. Therefore, to improve the contribution of stock market for sustainable economic growth, government and monetary authorities need to engage in implementing prudent and sound macroeconomic policies from the long-term perspective. When government securities traded value is considered as a fiscal policy tool, it is significant for government to reduce the accumulated public debt and obtain the normalization of domestic bond yield through promoting tax-based financing rather than government debt financing. For policy rate as a monetary policy instrument, it is crucial to obtain the benchmark policy rate among Asian economies with addressing significant factors affecting the too high policy rate including macroeconomic condition, balance of payment, exchange rate fluctuations, financial intermediation and domestic and foreign deposit holders base. 


\section{References}

Akitoby, B., \& Stratmann, T. (2008). Fiscal policy and financial markets. The Economic Journal, 533, 1971-1985.

Arestis, P., Demetriades, P. O., \& Luintel, K. B. (2001). Financial development and economic growth: The role of stock markets. Journal of Money, Credit and Banking, 33, 16-41.

Bank of Mongolia. (2010). The determinants of interest rate. Monetary Policy Division: Research PaperSeries, 10, 18-91.

Bekaert, G., \& Harvey, C. R. (1998). Capital markets: An engine for economic growth. The Brown Journal of World Affair, 5 , 33-53.

Bernanke, B. S., \& Kuttner, K. N. (2005). What explains the stock market's reaction to federal reserve policy? The Journal of Finance, 60, 1221-1257.

Calvo, G. A., \& Reinhart, C. M. (2000). Fear of floating. NBER Working Paper Series 7993, 1-31.

Caporale, G. M., Howells, P., \& Soliman, A. M. (2004). Stock market development and economic growth: The causal linkage. Journal of Economic Development, 29, 33-50.

Čihák, M., Demirgüç-Kunt, A., Feyen, E., \& Levine, R. (2012). Benchmarking financial systems around the world. World Bank Policy Research Working Paper WPS6175.

El-Wassal, K. A. (2013). The Development of stock markets: In search of a theory. International Journal of Economics and Financial Issues, 3, 606-624.

Enkhzaya, D., \& Dulguun, L. (2012). Financial intermediation. Bank of Mongolia: Research Paper Series, 7, 112-124.

Financial Regulatory Commission of Mongolia. (2016). Annual operational report. Retrieved from http://frc.mn/b/uatailan

Gan-Ochir, D., \& Batnyam, D. (2008). Mongolian capital market model: Impact of global financial crisis on capital market. Retrieved from http://mse.mn/uploads/files/File/content/hugjliin_tuv/RArticles/2009/4.pdf

Greene, W. H. (2003). Vector autoregressions and cointegration. In R. Banister, P. J. Boardman and G. Soto (Eds.), Econometric analysis. Pearson Education Limited: New York.

Hamilton, J. D. (1994). A new approach to the economic analysis of nonstationary time series and business cycle. In A. Harvey ( Ed.), Time series. Ashgate, Brookfield: Vermont.

Hilbers, P. (2005). Interaction of monetary and fiscal policies: Why central bankers worry about government budgets. IMF Seminar on Current Developments in Monetary and Financial Law: Washington.

Hsing, Y. (2003). Impacts of external debt and other macroeconomic policies on output in Brazil: A VAR approach. Revista de Analisis Economico, 18, 97-108.

Hsing, Y. (2011). Impacts of macroeconomic variables on the stock market in Bulgaria and policy implications. Journal of Economics and Business, 14, 41-53.

International Monetary Fund. (2017). Consultation and request for an extended arrangement under the extended fund facility_Press release; Staff Report; Statement by The Executive Director for Mongolia. Country Report 17/440.

Levine, R. (1991). Stock markets, growth, and tax policy. The Journal of Finance, 46, 1445-1465.

Levine, R., \& Zervos, S. (1998). Stock markets, banks, and economic growth. The American Economic Review, 88, 537-558.

Mishkin, F. S. (2016a). Monetary theory. In V. Ghose and P. Banerjee (Eds.), The economics of money, banking, and financial markets. Pearson Education Limited: England.

Mishkin, F. S. (2016b). An overview of financial system. In V. Ghose and P. Banerjee (Eds.), The economics of money, banking, and financial markets. Pearson Education Limited: England.

Mishkin, F. S. (2016c). Financial crisis in emerging economies. In V. Ghose and P. Banerjee (Eds.), The economics of money, banking, and financial markets. Pearson Education Limited: England.

Myagmarsuren, S. (2015). Financial deepening and its impact on real sector. Bank of Mongolia: Research Paper Series 10, 366-398.

Svirydzenka, K. (2016). Introducing a new broad-based index of financial development. IMF Working Paper WP/16/5.

Sahay, R., Čihák, M., N'Diaye, P., Barajas, A., Bi, R., Ayala, D., Gao, Y., Kyobe, A., Nguyen, L., Saborowski, C., Svirydzenka, K., \& Yousefi, S. R. (2015). Rethinking financial deepening: Stability and growth in emerging markets. IMF Staff Discussion Note SDN/15/08.

Taguchi, H., \& Enkhbaatar, N.(2019). Stock market and macroeconomic policies in Mongolia. Risk Market Journals: Bulletin of Applied Economics, 6, 21-39. 